Print ISSN: 2093-9582, Online ISSN 2508-4593

http://dx.doi.org/10.21871/KJFM.2020.3.11.1.45

\title{
Conflicts between Protected Franchise Territory and Unrestricted Delivery Trading Area*
}

\author{
Soo-Duck LEE** \\ Received: February 29, 2020 Revised: March, 2020 Accepted: March , 2020.
}

\begin{abstract}
Propose: The expansion of the delivery market in franchise business is a positive means of advertising and promotion for franchisees and contributes to substantial sales growth for stores. However, unrestricted and uncontrolled delivery sales and business activity of franchisee directly lead to encroachment of business territory between franchisees, resulting in increased operating costs of franchisees and conflicts between franchisees over rights and interests on franchise business. Moreover, in relation to the restrictions on the opening of competitors, it is incapacitating the law intent of prohibiting unfair encroachment of business territory, in the issue of the Fair Franchise Act in regard to guarantee of exclusive sales and business activity rights of franchisee. This study aims to point out major problems arising out of franchisee's infinite competition on delivery sales and business activity that are not restricted or controlled and then suggest legal supplements, policy tasks, and practical implications for improvement on the issues. Literature Review: In franchising business transactions, vertical restraints are associated with the exclusive territory establishment, control of transaction area, restriction of intangible sales and business activity of franchisee. Therefore, in the franchise business, it is necessary to take positive interpretation and application on e-commerce, the area of e-commerce, and delivery trading area and find proper and practical ways, by virtue of constructive attitude of each actor, to reduce the encroachment of business territory and various conflicts caused by unrestricted delivery trading area. Conclusion and suggestion: The finding shows that unrestricted or uncontrolled delivery sales and business activity of franchisees cause encroachment of business territory and many conflicts among franchisees. And this matters also weaken the legislation of the law on the protection of the business territory and can be negative factors that disrupt the protection of identity and sound development of the franchise industry in the long run. Therefore, in the franchise business, it is necessary to take positive interpretation and application on e-commerce, the area of e-commerce, and delivery trading area and find proper and practical ways, by virtue of constructive attitude of each actor, to reduce the encroachment of business territory and various conflicts caused by unrestricted delivery trading area.
\end{abstract}

Keywords : Franchise, Trading Area, Territory Encroachment, Vertical Restraints, Delivery E-commerce

JEL Classification Code : M10, M31, M38..

\section{1. 서론}

프랜차이즈 배달업종은 영업방식의 형태를 매장판매가 아닌 배달 판매와 영업을 기초로 한다. 이에 비해 매장형 외식 프랜차이즈 가맹점은 전통적으로 주방에서 조리된 메뉴를 매장에서 판매하거나 포장(take-out)의 방법으로 소비자와 거래를 해 왔다. 그러나 최근 배달 앱을 이용한 배달 판매·영업이 폭발적으로 확대되면서 매장이라는

${ }^{*}$ This paper was presented at the 2019 Fall Conference of the Korean Society for Franchise Management. Revised and Supplemented.

${ }^{* *}$ First Author, Adjunct Professor, Graduate School of Business, Sejong University, Seoul, Korea, Email: kevinelisa@naver.com

๑) Copyright: Korean Distribution Science Association (KODISA)

This is an Open Access article distributed under the terms of the Creative Commons Attribution NonCommercial License (https://creativecommons.org/licenses/by-nc/4.0/) which permits unrestricted non-
물리적으로 제한된 공간에 의존해 왔던 매장형 외식 프랜차이즈의 전형적인 판매.영업방식의 경계가 서서히 무너지고 있고, 이와 반대로 온라인 상거래인 배달 판매.영업방식의 중요성과 역할 비중은 점차 커지고 있다.

이들은 더 이상 매장 내의 판매.영업에만 의존하지 않고 소비자의 라이프 스타일의 변화와 소비방식의 변화에 능동적으로 대처하면서 최근 급성장하고 있는 푸드테크 산업을 적극 활용하여 지역 내 시장점유율 확대, 매출 증대, 매장의 광고홍보를 위해 적극적으로 배달 판매.영업방식을 강화하고 있는 것이다.

현재 배달업종을 제외하고 대부분의 매장형 외식 프랜차이즈의 배달 판매.영업은 가맹본부에 의해 제한되고 통제되지 않은 자유방임의 원리를 바탕으로 이루어지고 있어 가맹점 간의 무한 경쟁적 성격이 강해지고 있다. 
가맹점의 배달 판매.영업에 대한 무한경쟁은 시장에서 제품과 서비스에 대한 가격 및 품질의 경쟁을 촉발하여, 최종적으로 소비자의 후생의 증대는 물론 가맹본부의 물류매출의 확대에 기여하며, 가맹본부의 수익에도 긍정적이다. 또한 배달 판매.영업이 실질적으로 가맹점의 홍보와 매출증대에 상당히 기여하는 경우도 많아 가맹점의 영업이익 증대와 가맹본부의 시장점유율 확대에도 긍정적인 영향을 미친다.

그러나 다른 한편으로, 배달시장에 대한 가맹점 간의 무한경쟁의 상황은 현실적으로 배달 앱 광고료, 결제수수료, 배달료, 판매촉진비의 비용증가와 함께 가맹점의 노동 강도 및 운영의 피로감을 증가시켜 장기적으로 가맹점의 생존과 지속가능성에 부정적인 영향을 미칠 수 있다는 우려의 목소리가 높다. 그리고 가맹점 간의 배달사업에 대한 경쟁 격화로 인해 가맹본부의 브랜드 사업운영 효율성은 떨어지고, 가맹점과 가맹본부, 가맹점과 가맹점 간에 여러가지의 갈등과 분쟁을 촉진시키고 있다. 그 결과 무한경쟁의 배달상권으로 인해 발생하는 문제는 가맹본부의 사업 신뢰도를 하락시키고, 장기적으로 프랜차이즈 사업의 건전한 발전을 심각하게 저해시킬 수 있다는 것이다.

이처럼 배달사업의 긍정적, 부정적 영향이 상존하는 가운데, 본 연구가 주목하는 사실은 무한경쟁의 배달 판매.영업으로 인해 가맹점들은 스스로 인근 가맹점의 영업지역을 서로 상당히 침해하고 있다는 사실이다. 가맹점이 인근 가맹점의 영업지역을 침해하고 있다는 것은 자신이 가맹본부로부터 부여 받지 않는 영업지역에서 판매·영업을 한다는 것이고, 이에 따라 영업지역을 침해당한 가맹점의 매출은 하락하고 마땅히 보호되어야 할 가맹점의 권리와 이익은 훼손되고 있는 것이다.

가맹사업거래의 공정화에 관한 법률(이하 '가맹사업법) 제 12 조의 4 의 '부당한 영업지역 침해금지'의 법 규정은 특정 가맹점에게 설정된 영업지역 안에 정당한 사유없이 가맹본부의 직영점 또는 다른 가맹점의 출점을 금지하고 있고, 궁극적으로 설정된 영업지역에서 해당 가맹점의 독점적 판매권과 영업권을 보호하여 가맹점의 지속가능하고 안정적인 매출을 보호하는 것에 그 법의 취지가 있다.

그리고 프랜차이즈 사업형태가 다른 사업형태와 차별적인 이유는 상부조직인 가맹본부가 하부조직인 가맹점의 판매.영업방식과 거래지역의 제한에 대해 그 사실을 사전에 고지하고 이를 가맹계약 체결과정에서 설명함으로써 수직적 거래 제한을 할 수 있다는 데 있다.

그러나 현재의 가맹점의 자유방임 형태의 배달 판매.영업방식은 가맹점들 간의 영업지역 침해를 서로 부축이고 가맹사업법 제 12 조 4 의 법 규정의 존재의의와 그 가치를 점차 무력화시키고 있다. 더 심각한 문제는 배달 판매.영업을 하지 않는 가맹점들은 인근의 가맹점의 공격적인 배달 판매.영업에 의해 속수무책으로 영업지역의 침해를 당하고 있고, 이로 인해 계약과정에서 가맹본부로부터 정당하게 부여 받은 가맹점 운영의 권리와 이익이 보호받고 있지 못하고 있으며,
이러한 결과에 대해 가맹사업법은 뚜렷한 해결책을 제시해 주지 못하고 있다는 것이다.

현재까지 매장형 외식 프랜차이즈의 영업지역과 배달상권에 대한 연구는 아직 거의 없다. 그러나 현실에서 가맹사업법과 현재의 무한경쟁의 배달상권과의 불일치와 충돌의 문제는 매우 심각하다. 따라서 프랜차이즈 사업거래에 있어 배달 판매.영업의 사업방식이 점차 유력해지고 그 중요성이 부각되고 있는 현 상황에서, 온라인 상거래의 한 형태인 배달상권의 정의, 개념, 가맹사업과의 관계성, 파급효과에 대해 다양하고 폭넓은 연구의 필요성이 높아지고 있다.

이러한 연구의 필요성을 기초로 하여 본 연구에서는 첫째, 무한경쟁의 배달 판매 영업이 가맹사업법 제 12 조 4 의 '부당한 영업지역 침해금지' 와 어떠한 충돌이 일어나는지, 둘째, 무한경쟁의 배달 판매.영업에 대한 가맹본부의 제한 또는 통제가 가맹사업법 시행령 제 13 조 제(1)항 구속조건부 거래에 있어 부당한 사업활동의 제한과 어떠한 관계가 있는지, 셋째, 선행연구의 고찰을 통해 프랜차이즈 사업거래에 있어 수직적 거래 제한의 긍정적 기능과 역할을 파악하여 가맹사업법과 정책적 방향에 어떠한 개선안과 시사점을 제시할 수 있는지, 넷째, 프랜차이즈 사업거래에 있어 급격히 성장하고 있는 온라인 상거래, 온라인 상권, 배달상권에 대하여 어떠한 내용으로 가맹사업법의 보완 또는 개선이 이루어질 수 있는지, 다섯째, 이러한 전반적인 검토를 통해 현재의 가맹사업법의 영업지역과 사업활동의 제한의 사안에 대해 어떠한 법률적 보완과 개선이 가능한지, 마지막으로, 본 사안에 대해 주요한 관련 주체들이 어떠한 실무적 대처와 대응의 개선을 지향할 수 있는지에 대해 살펴보고자 한다.

본 연구의 목적은 현재 현장에서 발생하고 있는 무한경쟁의 배달상권의 문제점들을 완화 또는 최소화하기 위해 프랜차이즈 사업거래의 핵심 주체인 가맹본부, 가맹점, 공정거래위원회에게 법률적, 제도적, 정책적, 실무적 개선안과 시사점을 제시하기 위한 것이다. 따라서 최근 사회적으로 많은 이슈가 되고 있는 배달 앱에 관한 문제는 본 연구의 범위에서 최대한 축소 또는 배제시킬 것이다.

\section{2. 문제의 유형과 내용}

매장형 외식 프랜차이즈인 A 브랜드는 가맹사업법 제 12 조 4 의 '부당한 영업지역 침해금지'의 법 규정에 의하여 모든 가맹점의 영업지역을 사전에 설정해 주고 있다. 이에 따라 $\mathrm{A}$ 브랜드의 신사역점과 압구정역점은 각기 다른 배타적인 영업지역(exclusive tenitory)을 부여 받고 있다. A 브랜드는 대부분의 매장형 외식 프랜차이즈 브랜드처럼 가맹점의 배달 판매·영업에 대해 특별한 제한이나 통제가 없다. 이러한 여건은 다음의 질문들을 야기시킨다. 
Q1. 신사역점은 가맹계약서에 사전에 설정된 압구정역점의 영업지역의 안에서 자유롭게 배달 판매.영업을 하는 것은 아무런 문제가 없는가? 신사역점의 압구정점의 영업지역 침해(temitory encroachment)는 정당한가?

Q2. 매장형 판매 및 영업방식에 충실한 압구정역점이 배달 판매.영업을 하고 있지 않다. 이 상황에서 신사역점이 새롭게 압구정역점의 영업지역에 공격적으로 배달 판매.영업을 시작하였다. 이에 대해 압구정역점이 매출의 하락을 근거로 가맹본부에게 신사역점의 배달사업의 철수를 강력히 요구한다면 가맹본부는 신사역점에게 어떠한 조치할 수 있을까?

Q3. 현 가맹사업법 제 12 조 4 '부당한 영업지역의 침해 금지'는 가맹점에게 사전에 설정된 영업지역 내에 다른 가맹점 또는 직영점의 출점을 제한하여 궁극적으로는 해당 가맹점의 독점적 판매권 및 영업권을 부여하여 안정적인 매장매출과 운영을 이루어질 수 있게 함인데, 신사역점이 배달 판매·영업으로 압구정역점의 영업지역을 지속적으로 침해한다면, 제 12 조 4 의 법 취지는 유명무실한 것이 아닌가?

Q4. 배달을 둘러싼 가맹점들 간의 첨예한 경쟁을 줄이기 위해 $\mathrm{A}$ 가맹본부가 가맹점의 배달 판매.영업에 대한 거래지역(배달상권)을 설정해 주는 행위를 하는 경우, 동법 시행령 제 13 조 제(1)항 구속조건부 거래의 라목 '영업지역의 준수강제'와 마목 '그 밖에 가맹점사업자의 영업활동의 제한'의 금지의 법 규정에 의해 불공정거래행위에 해당되는가?

Q5. 신사역점이 논현역 지역에 배달 판매·영업을 통해 상당한 매출을 올리고 있다고 가정하자. 이 상황에서 논현역 인근에 신규 가맹점희망자가 가맹계약 체결을 위한 조건으로 배달시장을 선점한 신사역점의 논현역 지역의 배달영업의 철수를 요청한다면, $\mathrm{A}$ 가맹본부는 신사역점에게 그 철수를 주장할 수 있을까?

Q6. A 가맹본부는 이를 해결하지 못해 결국 논현역에 신규 가맹점을 출점하지 못하였다. 그 후 $\mathrm{A}$ 가맹본부는 신사역점과의 가맹계약기간 중 또는 계약갱신의 과정에서 논현역 인근에 신사역점의 배달 판매·영업을 하지 못하도록 가맹계약 내용의 변경을 요구하였는데, 신사역점은 매출하락이 예측된다며 이를 거부하였다. 그렇다면 A 가맹본부의 요구는 동법 시행령 제 3 호 거래상 지위의 남용의 다목 '부당한 계약조항의 설정 또는 변경'에 해당되어 불공정거래행위가 될 수 있는가?

위의 질문들은 가맹사업법의 영업지역 보호와 현재 무한경쟁으로 치닫고 있는 가맹점들의 배달 판매.영업과의 충돌로 인해 현재 발생하고 있는, 그리고 앞으로 충분히 발생할 수 있는 대표적 유형을 정리한 것이다. 본 연구에서는 이러한 대표적 유형의 설정을 통해 프랜차이즈 사업에 있어 빠르게 성장하고 있는 온라인 상거래인 배달시장으로 인해 현재의 가맹사업법이 직면한 문제를 용이하게
파악하고, 이를 통해 법률적, 제도적, 정책적 개선방안에 대한 진지한 논의를 할 수 있을 것이다.

\section{3. 배달산업, 배달시장, 배달 플랫폼}

\section{1. 관련 보고서들}

통계청이 2018 년 발표한 '장래가구특별추계: 2017 2047 년'의 보고서에 따르면, 1,957만 총 가구수는 2040 년에 2,265 만 가구로 정점을 찍고 이후 점진적으로 하락할 것으로 추계되었다. 2018 년 가구당 평균가구원수가 2.4 명에서 2047 년에는 2.03 명까지 떨어지고, 2018 년 1 인 가구의 수가 584 만으로 전체의 $29.3 \%$ 를 차지하지만, 2047 년에는 1 인 가구의 수가 832 만 가구로 $37.3 \%$ 로 이를 것으로 예측되었다. 2 인 가구의 수도 2047 년에 780 만 가구로 전체의 $35.0 \%$ 을 차지해 2047 년에는 1 인 가구와 2 인 가구의 합이 전체 가구의 $723 \%$ 로 압도적인 비중을 차지할 것으로 전망되었다.

아직 충분한 실증연구들이 없지만, 현재 배달시장의 급속한 성장의 요인은 인구통계학적으로 1 인과 2 인 가구의 증가 현상이 유력하게 지목되고 있고, 향후 평균가구원수의 감소와 1 인 및 2 인 가구의 증가의 추세는 배달산업의 발전을 받쳐 주는 주요한 요인으로 고려되고 있다.

이러한 추세를 반영하여 최근 배달시장에 대한 여러 실태조사와 분석들이 이루어지고 있는데, 닐슨코리아클릭 조사에 따르면, 2018 년 배달 앱을 통한 거래규모는 3 조 원대로 추정되며, 배달 앱 공급업자의 시장점유율은 배달의 민족(55.7\%), 요기요(33.5\%), 배달통(10.8\%)의 순으로 3 개의 공급자가 국내 배달시장을 독점하고 있으며, 월간 이용자 수는 배달의 민족(약 366 만명), 요기요(약 217 만 명), 배달통(약 71 만 명) 순으로 나타났다.

중소기업중앙회는 온라인 유통분야 공정거래 정착을 위한 개선방안 연구의 일환으로 '오픈마켓. 소셜커머스. 배달 앱 거래업체 애로실태조사'를 2018 년에 발표하였다. 이 보고서에 따르면, 프랜차이즈 가맹점이 $63 \%$ 포함된 총 303 개 사업자의 설문 결과, 업체당 평균적으로 2.19 개의 배달 앱을 거래하고 있었고, 배달 앱 가입 동기는 매출 증대가 $74.9 \%$, 매장의 광고·홍보가 $18.5 \%$ 이었으며, 배달 앱 가입 후 $792 \%$ 가 매출증대와 $72.7 \%$ 가 광고·홍보의 효과를 보고 있다고 보고하였다.

그러나 이러한 배달 앱에 대한 긍정적 답변에도 불구하고, 가맹점들은 광고비 과다(37.0\%), 광고수단 제한(7.9\%), 판매자에게 귀책사유의 일방적 책임 전가(7.9\%), 전용단말기 이용강제(63\%) 등을 배달 앱의 불공정거래 및 애로사항으로 지적하였다.

이 보고서들을 종합해 보면, 1 인 및 2 인의 가구의 증가, 소비자의 라이프 스타일의 변화, 편의성을 중시하는 소비방식의 변화로 인해 
배달시장은 빠르게 성장하고 있고, 이에 따라 프랜차이즈 가맹점은 배달 앱을 이용하여 적극적으로 자신의 매장을 광고 및 홍보하고, 그 결과 매출증대의 효과를 유의하게 경험하고 있으나, 다른 한편으로 많은 광고비 및 수수료의 부담, 가맹점 간의 격한 경쟁, 배달 앱의 불공정거래 행위에 대한 사안은 개선이 시급한 문제로 분석되었다.

\section{2 배달시장의 어두운 면들}

한국프랜차이즈산업협회는 2018 년 '배달 앱 문제 현황보고서'에서 편의성과 간편성을 추구하는 소비자의 라이프 스타일로의 변화로 인해 배달음식에 대한 선호도가 증가하고 있고, 이에 따라 프랜차이즈 가맹점의 배달 앱 사용도 증가하고 있다고 밝혔다.

그러나 분석 결과, 가맹점의 배달 앱 사용은 가맹점 매출에 일정 정도 도움이 되는 것은 사실이지만, 첫째, 주요한 배달 앱 플랫폼 3 개의 공급자가 시장점유율을 거의 모두 독식하고 있는 과점시장이라는 점, 둘째, 배달 앱의 과점형태는 가맹점이 높은 중개수수료와 광고료를 지불할 수밖에 없는 구조를 형성시키고 있다는 점, 셋째, 배달 판매.영업을 하지 않는 가맹점들은 인근의 배달 판매영업으로 영업지역의 침해와 권리와 이익이 보호받고 있지 못하는 점, 넷째, 프랜차이즈 브랜드가 독자 구축한 기존의 배달주문 시스템이 붕괴되고 있다는 점을 지목하면서 프랜차이즈 가맹점의 배달 앱 이용의 확대는 오히려 프랜차이즈 건전한 산업과 가맹점의 지속가능 경영에 위협적 요인이 되고 있다고 주장하였다.

배달 판매.영업에서 가맹점이 가장 하소연하는 것은 비용적 측면이다. 상거래 비용에서 배달의 민족은 외부결제수수료 $3 \%$, 오픈리스트 결제 시 $6.8 \%$ (오픈서비스 $5.8 \%$ 로 개편 예정), 요기요는 중개수수료 $12.5 \%$ 와 외부결제수수료 $3 \%$, 배달통은 중개수수료 $2.5 \%$ 와 외부결제수수료 $3 \%$ 를 가맹점으로부터 받고 있다.

문제는 이러한 거래수수료 외에 실질적으로 매출발생의 효과가 큰 광고비 지출이 만만치 않다는 점이다. 부가가치세를 제외하고 배달의 민족의 광고인 '울트라 콜', 요기요는 최고가 낙찰제인 우리동네플러스 광고 체계와 별도의 월 정액제 광고상품, 배달통은 광고상품별로 금액이 차별적인 광고상품을 운용하고 있다.

특히나 배달의 민족의 '울트라 콜' 광고 제도는 가맹점의 배달상권을 물리적 한계를 넓혀 매우 폭넓게 확대시켜 주는 유용한 기능에도 불구하고, 소위 '깃발꽂기'로 칭해지며, 가맹점 간의 영업지역 침해의 부정적 도구로 활용되고 있다. 그 이유는 배달 앱의 사업방식이 '울트라 콜과 이와 연계된 광고 시스템을 기반으로 하고 있기에 규모와 자본력이 큰 가맹점이 그 혜택을 독식할 수밖에 없는 구조적 결함 때문이다. 이러한 문제의 지적에 대해 최근 개수의 제한을 두는 '울트라
콜'의 개선안이 발표된 것도 이러한 '울트라 콜'의 부정적 영향을 제한 또는 최소화 시키기 위함으로 파악된다.

\section{020 commerce와 배달산업의 발전}

\subsection{0 commerce 의 발전과 소매업의 변화}

$\mathrm{O} 2 \mathrm{O}$ commerce(online to offline 과 offline to online)는 온라인과 오프라인의 상거래를 융합한 거래형태로써, 제품과 서비스에 대한 검색 및 결제는 온라인에서 하고 소비 자체는 오프라인에서 이루어지는 것을 의미한다(Du \& Tang, 2014; Tsai, Wang, Lin, \& Choub, 2015).

최근 모바일 기술의 발전과 다양한 소셜 네트워크 서비스(SNS) 산업의 폭발적인 성장은 소비자들의 소통하는 방식에 대한 변화뿐만 아니라, 기업의 마케팅, 광고 및 기업과 소비자의 상거래 방식까지도 급진적으로 변화시키고 있다. 전통적인 매장형 판매(bricks-and-mortar)와 온라인 판매(e-commerce)의 경계가 무너지고 상호 통합되고 있는 것이다(Tsai, et al, 2015).

$\mathrm{O} 2 \mathrm{O}$ commerce 는 소비자와 판매자 사이의 전통적인 대면 상거래f(face to face)가 아니기에 일반적 제품과 서비스에 대한 소비자의 구매과정과 평가체계가 다르다Kang \& Namkung, 2019). 과거 프랜차이즈 가맹점인 소매업자들은 매장에서 판매와 영업에만 충실했다.

그러나 $\mathrm{O} 2 \mathrm{O}$ commerce 의 발전은 소매업자들에게 그들의 사업 컨텐츠와 판매방식에 대해 변화를 요구하고, 온라인 판매에 대해 고객들의 반응이 어떠한 지, 그리고 최종효과가 어떻게 나타나는지 끊임없이 평가하기를 요청하고 있다(Tsai, et al, 2015).

$\mathrm{B} 2 \mathrm{C}$ 와 $\mathrm{C} 2 \mathrm{C}$ 와 같은 거래유형에 대한 접근과 달리, $\mathrm{O} 2 \mathrm{O}$ commerce 는 레스토랑, 문화상품, 위락시설 등 시설이용, 관광지 방문과 같이 소비 목적물 자체에 지향적이고, 지역적 상거래를 실질적으로 연결시키는 것에 초점을 맞추고 있다.

$\mathrm{O} 2 \mathrm{O}$ commerce 는 온라인 플랫폼으로 고객을 유인하고 상거래는 온라인으로 수행되지만, 소비 자체는 오프라인에서 직접 이루어지기에, 실제 해당 제품 또는 서비스를 경험하는 오프라인의 고객만족은 온라인과 오프라인 양쪽에서 평가되며, 소비자의 신뢰를 바탕으로 한 $\mathrm{O} 2 \mathrm{O}$ 플랫폼의 충성도는 $\mathrm{O2O}$ commerce의 성장에 매우 중요한 역할을 한다(Du \& Tang, 2014).

따라서 $\mathrm{O} 2 \mathrm{O}$ 시장은 기업과 소매업자가 고객을 확보하는데 소비자의 온라인과 오프라인의 일관성 있는 경험과 평가가 단절되지 않는 시스템 확보와 그 운영의 중요성을 강조하고 있다(Shen, Chen, \& Wang, 2019). 


\section{2 배달산업과 배달 플랫폼}

국내 시장에서 소비자의 일상생활과 깊게 관련된 $\mathrm{O} 2 \mathrm{O}$ commerce 는 숙박 앱에서는 '여기 어때', 부동산 중개 앱에서는 '직방', 택시 앱에서는 '카카오 택시'들이 시장을 선점하고 있고 그 외에도 티켓, 식당, 공연, 렌트 등 다양한 예약 시스템에 많이 응용되고 있다(Lee, 2019).

$\mathrm{O} 2 \mathrm{O}$ 음식 배달서비스는 모바일 앱이 보유한 기술적인 장점들과 소비자의 사용 편의성 등으로 인해 최근 급격히 성장하며 소비자의 라이스 스타일까지 변화시키고 있다(Roh \& Park, 2019). 소비자는 선택의 관여도가 낮거나 가격적 고려가 적은 음식들을 습관적으로 온라인 앱을 통해 주문하는 성향이 증가하고 있는데, 이러한 소비경향은 온라인 주문의 편리성과 신속성으로 기인되었다고 볼 수 있겠으나, 소비자의 관점에서는 바쁜 일상에서 시간절약(time-saving factor)을 하고자 하는 욕구도 상당히 반영되어 있다고 볼 수 있다(Yeo, Goh, \& Rezaei, 2017).

배달음식은 매장에서 조리된 음식을 배달원이 소비자에게 원하는 장소에 직접 전달해 주는 서비스이다. 배달음식에 기반한 배달산업은 오랜 시간 한국의 독특한 야식문화로 성장해 왔으며, 최근 푸드테크 산업의 발전, 1 인 가구의 증가, 편리성과 신속성 지향적인 소비자의 라이프 스타일의 변화, 다수의 배달 전문 대행업체의 등장과 함께 매우 가파르게 성장하고 있다.

배달산업의 발전에서 배달 앱은 매우 중요한 역할을 하는데, 배달 앱은 판매점과 소비자가 직접적 의사소통 없이 배달음식 검색, 주문, 결제, 평가를 한꺼번에 해결시켜주는 플랫폼을 말한다(Song, 2019; Song, Youn, \& Chen, 2019). 과거 전화를 통해 소비자가 직접 배달주문을 했던 것과 달리, 배달 앱은 '비대면 온라인 상거래 플랫폼'으로써, 공급자는 플랫폼을 통해 자신의 제품과 서비스를 판매하고 수요자는 플랫폼이 제공하는 제품과 서비스를 이용하며 플랫폼 사업자는 양측 또는 어느 한쪽에 플랫품 이용료를 부과하여 수익을 창출한다(Song, 2019).

배달산업의 발전은 신조어인 푸드테크(food tech) 산업의 성장과 맥을 같이하는데, 푸드테크는 식품(food)와 기술(technology)의 합성어로 음식이나 식품산업에 첨단 정보통신 기술을 접목하여 새로운 산업을 창출하거나 기존 산업에 부가가치를 더하는 것을 의미한다Chung, Choi, \& Choi, 2017; Kim \& Kim, 2016). 푸드테크 산업에서 배달 앱은 판매자와 구매자 사이에 상거래 중개 역할을 한다. 최근 배달 앱 서비스에 대한 소비자의 기대정도가 높아짐에 따라(Kim \& Kim, 2016), 소비자는 특정한 속성 또는 과정에 의해 제품 및 서비스에 대한 평가를 하지 않고 주문에서 소비까지 전체적인 과정, 예를 들어 할인쿠폰, 가격할인 혜택, 배달음식의 양, 배달된 음식의 품질, 배달원의 이미지, 배달 앱에서 제공하는 리뷰, 하물며 배달 앱에서 제공하는 정보의 신뢰성까지 포함하여 전반적인 관점에서 평가하는 경향이 증가하고 있다.

\section{3 온라인 상권, 배달산업, 배달상권의 조작적} 정의

상권은 궁극적으로 인간의 삶을 풍요롭게 하는 지역경제의 중심체로써, 제품과 서비스를 판매소비하는 일차적인 상업시장(commercial market)을 넘어 소비자가 다양한 문화를 생성·소비하는 문화시장(cultural market)이면서도 인간관계 촉진(human relationship promotion)의 활동이 복합적으로 일어나는 다차원적인 공간이다. 따라서 상권은 소비자의 일상생활과 매우 밀접하게 관련되어 있고 분리될 수 없는 경제적 공간(economic space), 문화적 공간(cultural space), 사회적 공간(social space)이 역동적으로 공존하는 복합적 공간이다(Lee \& Lee, 2018; Lee \& Lee, 2019).

전통적인 시각에서 상권은 소비자와 제품서비스 간의 상거래를 중심으로 이해되고 상점들이 밀집해 있는 지역으로 정의가 되었다(Jeong \& Yoo, 2000; Kim, Lee, \& Lee, 2016; Tae \& Rhim, 2010). 온라인 상권과 배달상권은 이러한 소비자와 공급업자의 일차적인 상거래 관점에 집중되고 이해될 수 있는데, 배달상권은 소비자와 상권과의 관계의 차원에서 다양하고 새로운 문화적 컨텐츠가 생산소비되는 문화적 공간과 인간관계의 상호작용이 일어나는 사회적 공간의 차원보다는 제품서비스가 배달이라는 거래방식에 의해 소비자에게 전달되어 소비가 되는 일차적인 상업시장의 성격이 매우 짙다고 할 수 있다.

본 연구에서는 상권은 Lee and Lee(2019)의 정의를 인용하고, 온라인 상권은 Du and Tang(2014)와 Tsai, et al.(2015)의 O2O commerce 의 정의를 수정하여 '온라인과 오프라인의 상거래를 융합한 거래형태로써, 제품과 서비스에 대한 검색 및 결제는 온라인에서 하고 소비 자체는 오프라인에서 이루어지는 상거래의 공간적 범위'라고 정의된다.

배달산업은 Song(2019)과 Song, et al.(2019)의 이해를 기초로 국내 배달시장의 현황과 발전의 특성을 반영하여 'O2O commerce 의 한 형태로, 소비자가 매장과 직접적 의사소통 없이 배달상품에 대한 검색, 주문, 결제를 배달 플랫폼을 통해 수행하고 배달 상품은 배달 전문 대행업체를 통해 전달되어 소비와 평가되는 배달 제품서비스와 관련된 비대면 온라인 상거래 산업'으로 정의된다.

배달상권은 전술한 배달산업의 정의를 바탕으로 매장의 직접 전화와 판매업자의 직접 배달을 제외하고 '배달 플랫폼으로 주문된 제품을 판매자가 배달 대행업체를 통해 소비자에게 전달할 수 있는 온라인 상거래가 가능한 공간적 범위를 말하고, 그 범위는 배달비용의 한계, 물리적 배달거리, 심리적 배달시간에 의해 제한된다'라고 정의된다. 배달비용의 한계는 배달 대행업체에 지불되어야 하는 비용인데 최종적으로 소비자 또는 판매자가 지불해야 하므로 일방 또는 양쪽이 수용 가능한 비용의 한계를 말한다. 
물리적 배달거리는 주문된 제품이 소비자에게 전달되는 배달과정에서 소요되는 시간으로 인해 제품의 품질저하가 필수적으로 일어나는데, 이에 대한 소비자가 수용이 가능한 품질적 한계를 말한다. 심리적 배달시간은 소비자의 처한 상황, 기대치, 그리고 주관적인 가치 평가체계에 의해 배달상품을 기다릴 수 있는 개인적 차원의 시간적 한계를 의미한다.

\section{5. 프랜차이즈 사업의 정의와 특성}

국내 프랜차이즈 사업은 가맹사업법 제 2 조에서 '가맹사업이라 함은 가맹본부가 가맹점사업자로 하여금 자기의 상표·서비스표·상호·간판 그 밖의 영업표지(이하 "영업표지"라 한다)를 사용하여 일정한 품질기준이나 영업방식에 따라 상품(원재료 및 부재료를 포함한다. 이하 같다) 또는 용역을 판매하도록 함과 아울러 이에 따른 경영 및 영업활동 등에 대한 지원·교육과 통제를 하며, 가맹점사업자는 영업표지의 사용과 경영 및 영업활동 등에 대한 지원·교육의 대가로 가맹본부에 가맹금을 지급하는 계속적인 거래관계"로 정의되고 있다.

프랜차이즈는 제품과 서비스의 공급업자가 소매업자의 가격, 광고, 판매, 상품구성 등에 감독 및 통제하고, 소매업자는 독점적으로 해당 공급업자에게 제품과 서비스를 공급받는 것으로, 본질적으로 독립된 경제단위의 사업에 관한 의사결정의 자유를 제한하는 독특한 시스템이다(Treece, 1967).

프랜차이즈 계약은 franchisor(이하 가맹본부)와 franchisee(이하 가맹점간의 법률 계약이다. 가맹본부는 판매할 제품과 서비스를 개발하고 이를 소유한 회사(parent fim)이고, 가맹점은 특정한 장소에서 해당 제품과 서비스를 판매하는 회사이다. 가맹본부는 가맹점에게 해당 사업을 운영할 수 있는 권리를 부여하고 그 대가를 받는다. 프랜차이즈 계약서는 가맹본부의 경영적 지원, 사업운영 방식, 로얄티(royalty) 지급, 계약 해지 및 종료, 가맹점 양도 등과 같은 기타 표준적 조항으로 구성되어 있다(Rubin, 1978).

따라서 프랜차이즈는 가맹본부가 소유하고 개발한 브랜드 이름과 시스템적 절차를 활용하여 제품 또는 서비스를 판매하는 가맹점과 가맹본부 사이에 체결된 법률 계약서를 기초로 한 사업의 형태이다(Lafontaine \& Shaw, 1999, Norton, 2004, Shane, 1996).

프랜차이즈는 가맹본부의 상호(trade name)를 이용하여 가맹점(downstream fim)이 가맹본부(upstream fim)의 운영방침과 관리통제 하에 사업을 운영하는 것으로, 19 세기 독일의 한 양조장이 지역의 술집(pubs)들에게 그의 상호를 이용하여 그들의 맥주를 팔 권리를 부여한 것에서 시작했다.
미국에서는 1860 년 McComick과 Singer Sewing Machine 사가 사업의 효율성을 높이기 위해 생산과 판매를 수직적 통합한 후, 이를 다시 분리하여 판매자(selling agency)를 통제하고 소매업자에게 독점적 판매권과 배타적 영업지역을 부여한 것에서 유래하였다(Dicke, 1992; Lafontaine \& Slade, 2014).

프랜차이즈는 목표시장의 진입을 위해 사업규모를 작게 하여 사업의 위험을 줄이고 인적 자본의 비용을 최소화하는 사업조직의 형태이기에, 가맹점은 사업 초기 자신의 사업이 프랜차이즈에 맞는지 아니면 독립체가 맞는지 결정하는 것은 매우 중요한 일이다(Michael, 1996).

프랜차이즈 사업은 특정 제품 및 서비스에 관한 산업 또는 지적인 자산의 독립적 권리에 대한 비즈니스 패키지로써(Norton, 2004), 가맹점은 가맹본부에게 그 패키지 사용의 대가로 초기 가맹금(initial fee)과 계속적 가맹금(ongoing royalty payment)에 기재한 계약서를 근거로 하여 약정된 금액을 지급하게 된다(Kaufmann \& Dant, 2001).

프랜차이즈는 독립된 가맹본부와 가맹점을 하나의 사업조직체의 형태로 운영되기에 두 당사자의 갈등이 발생하는 것은 자연스러운 것인데, Spinelli and Birley(1996)은 두 당사자의 갈등은 각자의 이익을 극대화하기 위한 거래비용 경제(transaction-cost economics) 측면에서 주로 발생하기에 이러한 상호 갈등을 줄이기 위해 조화와 적응(coordination and adaption)의 노력이 필요하다고 주장하였다.

\section{6. 수직적 거래 제한과 배타적 영업지역}

\section{1 수직적 거래 제한}

사업자 간의 불공정거래 행위가 될 수 있는 수직적, 수평적 거래 제한은 공정거래법의 근간으로써 1890 년에 제정된 셔먼 반독점법(Sherman Antitust Act)을 기초로 하고 있다.

수직적 거래 제한(vertical restraint)은 동일 브랜드 간 단독행위로 상부조직(제조업자)과 하부조직(소매업자와 판매업자)사이에 재판매 가격유지, 배타적 거래조건, 거래상대방 제한, 거래지역 및 판매지역 제한, 영업활동 제한을 말한다. 수평적 거래제한(horzontal restraint)은 이와 달리 다른 브랜드 간 공동행위로 다른 사업자와 가격 공모와 합의, 시장분할(market allocation), 생산량 제한, 공동 보이콧(거절)을 그 유형과 내용으로 하고 있다.

사업자 간의 수평적 거래 제한은 지금까지도 명백한 불공정거래행위로 당연위법(per se illegal)에 해당되지만, 수직적 거래 제한은 제조업자가 소매업자에게 판매 및 영업방식을 통제하고 독점적 판매와 영업권을 부여함으로써, 브랜드 운영비용의 감소를 통한 운영효율성 증대는 물론 동일 브랜드 소매업자의 판매 및 영업의 
과당경쟁을 방지하여 소매업자의 이익보호의 긍정적인 측면이 있기에 합리의 원칙(rule of reason)에 의해 불공정거래 행위의 부당성을 판단하고 있다.

프랜차이즈 사업은 이러한 수직적 거래 제한의 긍정적인 기능과 역할을 인정하여 이를 적용한 사업형태로, 가맹본부가 가맹점의 판매 및 영업방식의 제한, 거래물품의 제한, 거래가격의 권장, 거래지역 제한 또는 배타적 영업지역의 설정 등을 가능케 하는 이론적이고 법률적인 토대를 제공한다.

프랜차이즈 가맹본부의 엄격한 상표권 정책(trademark policy)으로 인한 갈등과 가맹본부가 가맹점에게 가격, 판매 및 영업방식, 영업지역 등 자율적 사업활동을 제한하는 수직적 제한은 시장에서 반독점적 문제를 유발시킨다(Treece, 1967).

프랜차이즈를 포함한 제조 및 공급업자의 소매업자에 대한 수직적 제한은 재판매가격유지(resale price maintenance), 배타적 영업지역 배분(dosed temitory distribution), 최소 주문수량의 강제(quantity forcing), 가맹금(franchise fees) 지급 등의 문제를 유발시키나, 가맹본부와 가맹점은 시장에서 서로 더 많은 이익을 창출과 운영의 효율성 증대를 위해 상호 수직적 제한에 동의하는 경향이 있다(Mathewson \& Winter, 1984; Rey \& Stiglit, 1988)

가맹본부는 자신의 사업위험을 독립된 가맹점과 공유(risk shaning)하여 사업위험을 분산시키고, 자신과 멀리 떨어진 매장의 관리비용을 절감을 통해 사업운영의 효율성을 높이며(location and monitoning costs), 사업 자금의 한계(capital market imperfections)를 극복하기 위해 프랜차이즈 사업거래에서 가맹점들과 수직적 통합(vertical integration) 또는 수직적 분리(separation)를 진행한다(Affuso, 2002).

경제적 관점에서 수직적 제한은 공급자와 소매업자의 이익을 극대화하고 운영의 효율성을 증대시키는 반면, 반경쟁적인 시장을 형성하고 소비자의 최종혜택을 감소시키는 이중성을 가지고 있는데, 배타적인 영업지역(exclusive teritonies)의 부여는 동일한 제품과 서비스를 판매하는 소매업자의 경쟁(inter-brand competition)을 줄이고 운영의 효율성을 증대시키는 대표적인 방법이다Rey \& Stiglit, 1988; Rey \& Stiglit, 1995; Sass \& Sauman, 1996).

그러나 경쟁적 시장에서 수직적 제한은 바람직한 상황이 아니라는 주장도 존재한다. 제조업자와 소매업자 사이에 가맹금 지급과 수직적 제한이 이루어지는 경우 제조업자는 시장에서 경쟁의 압력을 줄이면서 오히려 이중마진(double marginalization)을 취할 수 있기 때문이다(GalOr,1991; Rey \& Stiglitz, 1994). 또한 경쟁시장의 관점에서 수직적 제한의 대표적 형태인 배타적 영업지역의 부여는 최종적으로 소비자의 잉여(surplus)와 소비자의 전체 이익을 감소시킬 수 있는 문제점을 발생시킬 수 있기 때문이다(Lee, 2014; Rey \& Stiglit, 1994).

\section{2 배타적 영업지역 보호와 침해의 대립}

영업지역 보호와 침해의 사안은 가맹본부와 가맹점과의 관계에서, 그리고 가맹점들 간의 사이에서 매우 중요한 사안이다.

배타적 영업지역(exclusive temitory)의 부여는 브랜드의 성장을 저해하고 가맹점의 도덕적 헤이(moral hazard)를 유발하며, 가맹본부가 경쟁 가맹본부의 시장 침해에 적극적으로 대응을 불가능하게 하는 요인이 된다는 반대론자와 가맹점의 안정적인 운영을 보장하고 가맹점의 거래특유투자에 대한 가맹점의 이익을 보호하여 가맹본부와 가맹점의 신뢰관계를 유지에 도움이 될 수 있다는 옹호론자의 의견은 서로 대립되고 있다(Lim, 2014; Lim, Lee, \& Kim, 2012).

배타적 영업지역은 제조업자가 소매업자에게 특정 지리적 지역에서 브랜드의 독점적인 판매와 영업의 권리를 보장해 주는 것을 말하는데, 일반적으로 프랜차이즈 사업형태와 주류 유통산업에서 수직적 제한인 배타적 조건부거래(exclusive dealing)로 나타난다(Lafontaine \& Shaw, 1999; Sass \& Sauman, 1996)

배타적 조건부거래는 주로 제조업자가 소매업자에게 오직 자신의 제품을 판매하게 하거나, 특정 거래상대방과 거래를 조건화하고 또는 특정한 거래조건의 계약적 조건에 기초로 하여 판매를 계약하는 거래를 말하는데, 특히 프랜차이즈 사업에서는 매우 보편적인 사업형태이다(Lafontaine \& Shaw, 1999).

가맹본부는 그들의 가맹금의 수익을 늘리기 위해 기존 가맹점 인근에 새로운 가맹점의 출점을 원하지만, 기존 가맹점은 인근에 동일한 경쟁 가맹점의 출점을 원하지 않기 때문에 두 당사자의 이해관계가 불일치 나고 갈등이 유발된다(Nair, Tikoo, \& Lu, 2009).

프랜차이즈 시장의 효율성과 소비자의 후생을 놓고 프랜차이즈 영업지역 침해에 관해 법학자, 경제학자, 경영학자는 서로 많은 논쟁을 해 왔다. 가맹점의 출점으로 인한 영업지역 침해는 해당 지역의 소비자들을 기존의 가맹점으로부터 떼어 놓고 기존 가맹점의 매출을 충분히 감소시킬 만큼 기존의 가맹점의 가까운 인근에 새로운 가맹점의 출점을 승인하는 것을 말한다(Benoliel, 2011; Vincent, 1998).

Benolie(2011)는 이러한 논쟁이 긍정적인 효과를 내려면 단기적인 관점이 아닌 장기적인 관점에서 평가해야 한다고 주장하였다. 가맹본부가 신규 가맹점의 출점으로 기존 가맹점의 영업지역 침해를 하거나 이를 방관한다면, 기존 가맹점은 영업지역 침해로 인해 발생하는 자신의 이익감소에 대해 가맹본부에게 법적 책임을 물을 것이다. 그러한 분쟁의 사실은 신규 가맹희망자에게 자신도 미래에 그렇게 될 수 있다는 불안감을 유발시키고 가맹희망자의 출점의도를 단기적으로 감소시킬 수 있다. 또한 이를 관철시키려는 가맹본부는 기존 가맹점과 분쟁에 휘말릴 수 있고, 그 과정에서 일부 가맹점을 계약해지를 해야 하는 어려움까지 감당해야 하기 때문이다. 
Kalnins(2004)는 1990 년 대 Texas 의 숙박업소의 분석을 통해 기존 가맹점 부근(vicinity of incumbent units)에 신규 가맹점이 출점되는 경우 기존 가맹점의 매출은 유의하게 줄었다는 사실을 증명하였다. 가맹본부는 인근 신규 출점이 가능지역을 비워두는 것은 어차피 다른 브랜드 가맹본부의 가맹점이 출점할 수 있기에 브랜드 보호와 전체 사업의 성장의 관점에서 옳지 않다고 주장하지만, 인근 가맹점의 신규 출점으로 기존 가맹점의 매출이 줄 수 있기에 가맹점들은 자신의 영업지역을 배타적으로 보호해주는 가맹본부를 선호한다고 주장하였다. Nair et al.(2009)는 이러한 영업지역 독점권 또는 배타성(teritorial exclusivity)과 영업지역 침해(ternitory encroachment)의 갈등의 해결책으로 가맹점이 인근의 특정 지역의 영업지역 독점권을 사전에 구매하고 가맹본부는 계약서에 이를 보장해 줌으로써 감소시킬 수 있다고 제안하였다.

기존 가맹점 인근에 신규 가맹점 출점으로 인한 영업지역 침해의 문제는 단순히 가맹점과 인근 가맹점의 문제가 아니다. 신규 가맹점의 출점으로 인한 기존 가맹점의 영업지역 침해로 유발되는 매출의 감소와 권리침해의 문제는 두 당사자의 문제를 넘어 정치적이고 정책적인 문제로 확산될 수도 있다(Kalnins, 2004). 또한 최근 가맹본부가 자체 운영하고 소비자에게 직접 제품서비스를 판매하는 온라인 상거래 웹페이지는 가맹본부 스스로가 자신의 가맹점들의 영업지역을 사업 전략적으로 침해하고 있다.

프랜차이즈 산업에서 $\mathrm{O} 2 \mathrm{O}$ commerce의 발전은 소비자가 가맹본부의 온라인 상거래 웹사이트에서 주문하는 것을 촉진시키고 있지만, 한편으로 가맹점을 상품들의 쇼룸(showroom)으로 전락시키고 있는 어두운 면도 공존한다. 가맹본부의 e-commerce 의 확대는 결국 가맹본부가 가맹점의 영업지역을 침해하는 것으로, 가맹점의 판매와 영업을 위축시켜 가맹점의 전체 매출을 자기잠식(cannibalization)시키는 요인이 되기도 한다(Cliquet \& Voropanova, 2016).

\section{7. 법률적 검토}

\section{1 공정거래법}

공정거래법은 제 23 조 '불공정거래행위의 금지'조항에서 '사업자는 공정한 거래를 저해할 우려가 있는 행위를 하여서는 아니된다'라고 명시하고 있다. 본 조항의 제1)항 가운데 제 5 호는 '거래의 상대방의 사업활동을 부당하게 구속하여 거래하거나 다른 사업자의 사업활동을 방해하는 행위'를 불공정거래행위로 규정하고 이를 금지하고 있다.

본 법률의 시행령 제 36 조는 구체적으로 법률에서 정한 불공정거래행위의 유형과 기준을 명시하고 있다. 상위 사업자의 하위
사업자에 대한 거래지역 제한, 영업지역 지역 제한, 그리고 자유로운 사업 및 영업활동의 제한 등 수직적 거래 제한에 대한 문제는 동 시행령 제(1)항의 '구속조건부거래'에서 가목의 '배타적 조건부거래'와 나목의 '거래지역 또는 거래상대방의 제한 상품 또는 용역을 거래함에 있어서 그 거래상대방의 거래지역 또는 거래상대방을 부당하게 구속하는 조건으로 거래하는 행위'로써 조리위법의 사안으로 불공정거래행위의 유형에 포함시키고 있다.

\section{2 가맹사업법}

가맹사업법은 가맹본부와 가맹점사업자 사이의 불공정거래행위의 유형을 구체화하면서도, 한편으로 특정한 요건을 갖추었을 때 가맹본부의 수직적 거래 제한을 일정 범위 내에서 인정을 하고 있다.

가맹사업법에 명시된 수직적 거래 제한은 큰 틀에서 가맹점의 무형의 사업활동 제한과 부동산 관점에서 경쟁 가맹점의 유형의 물리적 출점 제한을 통한 영업지역의 보호의 두 가지 영역으로 분류되지만, 계약기간 중 또는 갱신과정에서의 부당한 계약조건을 변경 또는 강요 금지에 대한 법 규정도 상호 연계되어 아래와 같이 하위차원으로 함께 이해될 수 있다.

첫째, 가맹계약기간 중 가맹점사업자의 자유로운 판매활동과 영업활동, 마케팅 활동 등(이하 사업활동) 무형의 사업활동에 관하여 동 법률 제 12 조 제(1)항 제 2 호와 시행령 제 13 조 제(1)항 '구속조건부 거래'의 라목 '영업지역의 준수강제'와 마목 '그 밖에 가맹점사업자의 영업활동의 제한'에서 가맹본부가 이를 부당하게 제한 또는 구속하지 못하도록 하고 있다.

이는 가맹점사업자가 갖는 사업활동에 대해 자유롭고 공격적 차원(offense)의 권리로써 가맹본부가 부당하게 그 활동의 제한을 하지 못하도록 한 것이다.

본 법 규정은 서론에서 질문한 $\mathrm{Q} 1, \mathrm{Q} 2, \mathrm{Q} 3, \mathrm{Q} 4$ 와 관계된 사안으로, 무한경쟁의 배달상권과 가맹점의 영업지역 침해의 갈등의 문제에 핵심적으로 적용되는 사안이다. 왜냐하면 배달상권의 제한 또는 통제는 가맹점의 무형의 자유로운 사업활동의 제한 또는 통제를 의미하고, 현재 가맹사업법에서 가맹점의 배달 판매.영업을 가맹본부가 제한 또는 통제하는 행위가 법률적으로 부당하지 않는가에 대한 직접적 질문이 되기 때문이다.

현실적인 실무의 영역에서, 대부분의 매장형 외식 가맹본부는 해당 법 규정으로 인해 배달상권을 제한 또는 통제하는 것이 불가능하다는 관점으로 이해하고 있고, 그러한 이유로 가맹본부들은 가맹점의 배달 판매.영업에 대해 자유방임의 원리로 대처하고 있는 사례들이 많다. 
그렇다면 현재의 가맹사업법에서 가맹본부가 가맹점사업자의 배달상권을 제한 또는 통제하는 것이 원천적으로 불가능한가? 원론적으로 그러하지 않다.

먼저, 본 시행령 제 13 조 제(1)항 '구속조건부 거래'의 라목 '영업지역의 준수강제(부당하게 가맹점사업자에게 영업지역을 준수하도록 조건을 붙이거나 이를 강제하는 행위'의 제외요건으로 (1)가맹본부가 가맹점사업자의 영업거점지역을 정하는 행위, (2)가맹점사업자가 자기의 영업지역에서의 판매책임을 다한 경우에 영업지역 외의 다른 지역에서 판매할 수 있도록 하는 행위, (3) 가맹점사업자가 자기의 영업지역 외의 다른 지역에서 판매하고자 하는 경우 그 지역의 가맹점사업자에게 광고선전비 등 판촉비용에 상당하는 일정한 보상금을 지불하도록 하는 행위 가운데 어느 하나에 해당되는 경우 불공정거래행위에 해당되지 않기 때문이다.

다시 말해, 세 가지의 요건 중에 하나만 만족하면 가맹본부가 가맹점의 사업활동 가운데 영업지역 준수를 강제할 수 있다는 것이다.

제(2)요건과 제(3)요건의 경우는 객관적인 증빙과 상호협의 어려움이 있어 실무적으로 이행되기에는 쉽지 않다. 그러나 가맹본부가 제(1)요건을 가맹본부가 사전에 준비하여 매뉴얼을 만들고, 정보공개서와 가맹계약서에 이를 미리 밝힘과 동시에 가맹계약 체결과정에서 가맹점사업자에게 충분히 설명한다면 이 제외요건을 기초로 가맹점의 배달상권의 제한 또는 통제는 법률적으로 가능해 보인다.

다만, 본 시행령의 '영업지역의 준수강제'는 법률 제 12 조 4 의 '부당한 영업지역 침해금지'의 유형의 물리적 가맹점 출점과의 달리 가맹점의 판매, 영업, 마케팅과 관련된 등 무형의 사업활동의 제한을 말하는 것이라는 점을 확실히 구별해야 한다.

다음은 시행령 제 13 조 제(1)항 '구속조건부 거래'의 마목 '그밖에 가맹점사업자의 영업활동의 제한(가목 내지 라목에 준하는 경우로서 부당하게 가맹점사업자의 영업활동을 제한하는 행위)'을 수직적 거래 제한으로써 가맹점의 배달상권의 제한 또는 통제에 적용할 수 있는지의 여부이다.

본 법 규정에서 (1)가맹점사업자의 영업활동을 제한하지 아니하는 경우에는 가맹본부의 상표권을 보호하고 상품 또는 용역의 동일성을 유지하기 어렵다는 사실이 객관적으로 인정될 것, (2)가맹본부가 미리 정보공개서를 통하여 가맹점사업자에게 해당 사실을 알리고 가맹점사업자와 계약을 체결할 것을 예외요건으로 명시하고 있는데, 두 개의 제외요건을 모두 충족하는 경우 불공정거래행위로 보지 않는다.

그러나 배달상권은 가맹본부의 상표권 보호와 사업의 동일성의 유지와 관계된 제(1) 요건에 대해 직접적인 내용의 관련성이 적기에, 이 법 규정을 기초로 미리 정보공개서와 가맹계약서에 해당 사실을 알리고 가맹계약을 체결하더라도 이를 근거로 배달상권의 제한 또는 통제의 영업활동을 제한하기에는 논리적으로 쉽지 않다.
따라서 가맹점의 배달상권에 대해 가맹본부가 이를 제한 또는 통제하는 것은 가맹본부가 가맹점의 사업활동을 제한 또는 통제하는 것으로, 가맹본부는 시행령 제 13 조 제(1)항 '구속조건부 거래'의 라목 '영업지역의 준수강제' 금지의 제 (1)의 제외요건인 (1)가맹본부가 가맹점사업자의 영업거점지역을 정하는 행위를 기초로 하여 무한경쟁의 가맹점의 배달상권을 제한 또는 통제할 수 있는 여지가 충분히 있다고 할 수 있다.

둘째, 동 법률 제 12 조 4 '부당한 영업지역 침해금지'의 법 규정은 가맹계약서 체결과정에서 가맹본부에게 영업지역을 설정하는 의무를 부과하고 있고, 가맹계약기간 중에 이를 변경하고자 하는 경우 가맹점사업자와 협의해야 한다고 명시하고 있다.

본 법 규정은 전술한 가맹점의 무형의 사업활동과 달리, 부동산 관점에서 점포출점에 관한 것으로 사전에 설정된 영업지역 내에 정당한 사유없이 다른 가맹점 또는 직영점의 출점을 막기 위한 방어적 차원(defense)이다.

본 사안은 서론에서 질문한 $\mathrm{Q} 3$ 과 직접적으로, Q1, Q2, Q4 와는 간접적으로 연계되어 있는데, 무한경쟁의 배달상권으로 인한 가맹점 간의 영업지역의 침해의 문제가 심각하게 부각되면서 최근에는 이 법 취지와 존재의의성이 상당히 흔들리고 있다.

이 법의 취지는 가맹점의 영업지역을 가맹계약 체결과정에서 사전에 설정, 이를 보호하여 인근지역에 경쟁적 가맹점 또는 직영점의 출점을 막아 해당 가맹점이 안정적이고 지속가능한 매출을 올릴 수 있도록 가맹본부의 수직적 거래 제한을 인정해 주는 것이다. 그러나 이 법 규정을 통해 경쟁 가맹점 또는 직영점의 출점의 제한을 할 수 있으나, 인근 가맹점이 무형의 배달 판매.영업으로 자신의 설정된 영업지역에서 사업활동을 하는 것은 방어할 수 없다. 여기서 모든 충돌과 대립이 발생한다.

본 법 규정이 인근 경쟁점의 물리적 출점을 제한하고 궁극적으로 가맹점에게 사전에 협의된 특정한 지역에 독점적 판매권과 영업권을 부여하는 것임에도 불구하고, 현실적이고 실무적 차원에서 제 13 조 제 1 항 '구속조건부 거래' 라목과 마목에 의해 무형의 배달상권을 제한 또는 통제하는 것은 불공정거래행위에 해당될 수 있어 많은 매장형 외식 가맹본부들이 본 사안에 대해 매우 소극적이고 보수적으로 대처하고 있다.

셋째, 동 법률 시행령 제 13 조 '거래상 지위의 남용'의 다목 '부당한 계약조항의 설정 또는 변경' 금지의 법 규정은 '가맹본부가 가맹점사업자가 이행하기 곤란하거나 불리한 계약조항을 설정 또는 변경하거나 계약갱신과정에서 종전의 거래조건 또는 다른 가맹점사업자의 거래조건보다 뚜렷하게 불리한 조건으로 계약조건을 설정 또는 변경' 하는 것을 조리위법의 불공정거래행위라고 명시하고 있는 것을 말한다. 
이 사안은 서론에서 질문한 $\mathrm{Q} 2, \mathrm{Q} 5, \mathrm{Q} 6$ 에 해당되는데, 그동안 존재하지 않고, 없었던 것을 가맹본부가 새롭게 만들어 제한 또는 통제하는 것을 말한다.

A 가맹본부가 배달상권의 제한 또는 통제에 대한 매뉴얼, 정보공개서의 기재사항, 가맹계약서의 통제 조항을 가지고 있지 않은 상태에서 신규 가맹점의 출점 또는 가맹본부의 경영적 이유로 인해 신사역점의 배달지역을 새롭게 제한 또는 통제하거나 이를 계약조건으로 설정 또는 변경을 가맹점에게 요구하는 행위가 부당한 불공정거래행위가 된다면 아마도 모든 가맹본부들이 현재의 자유방임의 배달상권에 대해 어떠한 개선을 하고자 하지 않을 것이다.

실제로 최근 신규 가맹점의 출점과정에서 선점된 인근 가맹점의 배달 판매영업에 대한 문제가 발생하는 사례가 종종 나오고 있는데, 향후 가맹점 출점 반경이 좁은 다점포 출점전략의 브랜드나 특정지역에 많은 가맹점을 보유하고 있는 브랜드에게 본 사안은 매우 다루기 어려운 문제가 될 것이다.

\section{8. 관련 주체들의 주요한 입장들}

현재 매장형 외식 프랜차이즈 가맹점은 지역 시장점유율의 측면에서 경쟁점들에게 밀리지 않기 위해 배달 앱을 어쩔 수 없이 사용해야 하는 상황에 봉착해 있다. 가맹점사업자는 배달 앱을 통하여 매출증대와 매장의 광고홍보의 효과를 체감하고 있지만, 다른 한편으로 배달 앱 이용료, 광고료, 유지관리비 등 비용의 문제와 인근 가맹점 간의 영업지역의 침해의 문제 등으로 인하여 현재 매장운영에 많은 어려움이 있는 것도 사실이다.

가맹점들은 자신의 지역에서 동일 브랜드 간에 배달 판매.영업의 첨예한 경쟁이 줄고, 자신의 영업지역이 안정적으로 보호되는 것을 원한다. 따라서 가맹점들이 현재의 무한경쟁의 배달 판매.영업으로 발생하는 문제를 더 이상 가맹점 간의 싸움으로 방치하지 말고, 정책기관과 가맹본부가 좀 더 적극적으로 나서서 이 문제를 해결해 줄 것을 요구하는 것은 당연한 일이다.

그러나 가맹본부는 경쟁적인 가맹점의 배달 판매영업이 물류매출의 증대에 기여하는 측면이 있기에 의도적으로 가맹점의 배달상권을 제한 또는 통제를 하지 않는 경우도 있을 수 있으나, 상당한 수의 가맹본부는 시행령 제 13 조에 명시된 영업지역 준수 강제하거나 가맹점의 사업활동 제한이 부당한 위법적 행위가 될 수 있기에 본 사안에 소극적이고 보수적 자세를 취할 수밖에 없다는 항변을 묵과할 수도 없다.

한편, 공정거래위원회는 본 사안에 대해 아직 대외적으로 뚜렷한 입장이 없다. 현재의 가맹점의 배달 판매영업방식이 장기적으로
프랜차이즈 사업의 정체성을 흔들고 건전한 발전을 저해할 수 있다는 위기감을 인식하지 못하고 있는 것 같다. 현재로써는 가맹본부가 가맹점의 배달 판매.영업을 제한하는 것에 대한 부당성은 개별 사건의 관점에서 그 여부를 판단할 것으로 보여진다.

배달 앱 공급업자의 입장을 보면, 대표적으로 배달의 민족에서 '지오펜상' 등 가맹점 간의 판매지역을 제한할 수 있는 시스템을 운용하고 있으나, 기본적으로 본 사안은 가맹본부와 가맹점 간의 두 당사 간의 문제이기에 직접적인 해결 주체로 나서지 않고 있다.

다만 최근 많은 문제가 되고 있는 배달 앱 광고방법을 오픈리스트로 전환하고 울트라 콜의 이용갯수의 제한과 같은 변화를 꾀하고 있으나, 아직까지는 가맹점들의 불만을 충분히 포용하기에는 부족한 것으로 보인다.

정리하자면, 매장형 외식 프랜차이즈의 무한경쟁의 배달 판매.영업으로 인해 발생하는 문제들에 대해 아직까지는 가맹점, 가맹본부, 정책기관, 배달 앱 공급업자 등이 각자의 입장과 주장만 있을 뿐이지, 어느 누구도 먼저 문제의 심각성을 피력하고 적극적으로 그 해결방안을 찾기 위해 앞으로 나서지 않고 있는 실정이다.

\section{9. 개선과 시사점}

\section{1 가맹사업법의 보완 및 개선}

첫째, 혼란을 유발하는 법률적 용어를 빠른 시간 내에 개선할 필요가 있다.

'부당한 영업지역 침해 금지', '영업지역 준수 강제', '영업거점지역'의 법 취지와 그 내용이 서로 분명히 다름에도 공통적으로 표현된 '영업지역'으로 인해 많은 혼동을 주고 있다.

법률 제 12 조 4 '부당한 영업지역 침해금지'의 영업지역은 가맹점을 중심으로 인근 경쟁점의 유형의 물리적 출점을 제한할 수 있는 지리적 범위와 관계되어 있다. 본 법 규정의 영업지역은 실제로 가맹점의 판매활동, 영업활동, 마케팅 활동 등 사업활동을 의미하는 것이 아니라, 다른 경쟁점이 출점을 할 수 없도록 특정 가맹점에게 보장되고 보호되는 지리적 범위일 뿐이다. 따라서 법률 제 12 조 4 의 '영업지역'에서 '영업'이라는 단어는 실제 가맹점의 영업활동과 관련성이 없다.

이에 비해, 법률 제 12 조 제(1)항 제 2 호와 시행령 제 13 조 제(1)항 '구속조건부 거래'의 라목 '영업지역의 준수 강제'의 법 규정의 '영업지역'은 일반적으로 일컬어지는 판매활동, 영업활동, 마케팅 활동 등 무형의 사업활동을 말한다. 
가맹본부가 부당하게 가맹점의 자유로운 사업활동을 특정지역 내로 제한하는 경우 불공정거래행위에 해당될 수 있다는 것이다. 예를 들어, 신사역점에게 신사역 인근에서만 판매 및 영업활동을 하도록 거래지역을 부당하게 제한하는 경우에 해당된다. 따라서 '영업지역의 준수 강제'에서 '영업지역'은 가맹점의 무형의 사업활동을 의미하기에, 법률 제 12 조 4 의 영업지역과 본질적으로 차이가 있다.

본 시행령 '영업지역의 준수 강제'의 제(1)의 제외요건인 '가맹본부가 가맹점사업자의 영업거점지역을 정하는 행위'에서 '영업지역'도 마찬가지다. 여기에서 '영업거점지역'도 지리적 범위의 영업지역이 아닌 '거점이 포함된 가맹점의 무형의 사업활동의 범위'를 의미한다. 그러나 일반적으로 '거점'이라는 단어는 무형의 사업활동이 아니라 점포나 매장을 의미하는 부동산적인 개념이 짙기 때문에, 여기에서 영업거점지역은 개념적으로 올바른 표현으로 여겨지지 않는다.'

이러한 논리적 기초로 본 연구에서는 영업지역과 관련하여 법률적 혼동을 최소하기 위해 첫째, 법률 제 12 조 4 의 '부당한 영업지역 침해 금지'의 영업지역을 법의 취지와 그 내용에 부합하게 '출점지역'의 용어로 대체하여, '부당한 출점지역 침해 금지' 또는 '출점지역의 부당한 침해 금지'로 수정하는 것을 제안한다.

'영업지역 준수 강제'에 대해서는 본 법률 내용이 가맹점의 판매활동, 영업활동, 마케팅 활동 등 전체적인 사업활동을 의미하므로, '부당한 사업활동의 제한' 또는 '부당한 판매 및 영업활동의 제한'으로의 수정을 제안한다.

마지막으로, '영업거점지역'은 가맹점의 사업활동의 범위를 말하는 것이고 '거점'은 일반적으로 부동산적 차원의 지리적 위치를 말하는 것이기에, 본 연구에서는 '영업거점지역'을 '사업활동 지역' 또는 '판매 및 영업활동 지역'으로 수정하는 것을 제안한다.

둘째, 정책기관과 가맹본부는 법률 제 12 조 4 의 '부당한 영업지역 침해 금지'의 법 취지가 제한 또는 통제되지 않는 무한경쟁의 배달상권으로 인해 이미 그 법 취지가 쇠퇴하고 무력화되고 있고 이러한 상황은 장기적으로 프랜차이즈의 건전한 발전에 부정적인 영향을 미칠 것이라는 사실을 심각하게 인식해야 한다.

자신의 영업지역이 보호가 되지 않는 프랜차이즈 사업에 대해 가맹희망자는 어떠한 사업적 매력을 느끼지 않을 것이기 때문이다.

동 법률에 입각하여 가맹점은 가맹본부와 협의하여 사전에 설정된 영업지역 내에서 독점적 판매권과 영업권을 보장받기에, 가맹점은 많은 비용을 투자하여 가맹계약을 맺고, 계약 초기 그리고 계약기간 중에 그 댓가로 가맹본부에게 로열티를 포함한 가맹금을 지급한다.

전술한 것처럼 원론적으로 사맹사업법도 프랜차이즈 사업의 거래지역에 대한 수직적 제한의 순기능을 인정하고 있다. 그러나 현재의 무한경쟁의 배달상권은 인근 가맹점에 사전에 설정된 영업지역의 보호를 불가능하게 만들고 있기에 프랜차이즈 사업에서
배달시장이 확대될수록 이 법 규정의 역할과 기여는 점차 약화될 것이다.

셋째, 이러한 이유로 정책기관이나 법학자들은 법률 제 12 조 4 의 법 취지를 보호하고 보완하기 위한 노력이 필요하다. 그 보완책으로 본 연구에서는 이제는 가맹사업법 안에 온라인 상거래, 온라인 상권, 배달 상권의 정의와 역할의 내용을 포함하고 이를 명시하는 것을 진지하게 고민해야 한다고 제안하고자 한다. 최근 권리금에 대한 법률적 정의와 회수과정에 대한 법적 절차와 방법이 상가임대차보호법에 명시된 것처럼, 가맹사업법도 본 사안에 대하여 법률적 수용을 통해 명확한 법 규정을 기재하여 가맹점의 영업지역 침해를 실질적으로 완화시킬 수 있는 개선안을 마련할 필요가 있다.

넷째, 프랜차이즈 사업거래에서 앞으로 더욱 성장할 온라인 상거래, 온라인 상권, 배달상권에 대해 규정된 법적 정의와 그 내용을 기초로 법률 제 12 조 4 에 대한 보완하는 것뿐만 아니라, 법률 제 12 조 제(1)항 2 호, 시행령 제 13 조 제(1)항 구속조건부 거래'라목 '영업지역 준수 강제'와 마목 '그밖에 가맹점사업자의 영업활동의 제한'의 법 규정을 보완하고 수정하여 가맹본부가 건전한 방법으로 이를 활용할 수 있도록 법률적 지원을 할 필요가 있다. 배달을 통한 온라인 상거래는 고객이 매장에 직접 매장을 방문하는 전통적 거래형태가 아닌 보이지 않고 추상적인, 쉽게 말하자면 땅이 아니라 하늘에서 이루어지는 상거래로 설명될 수 있다. 이미 매장형 외식 프랜차이즈 사업거래에서 온라인 상거래는 매우 유력한 사업의 형태가 되었고 향후 그 중요성은 더 커질 수밖에 없기에, 현재의 가맹사업법의 구속조건부 거래의 라목과 마목의 법 규정은 이러한 소비자의 변화와 사회적 현실을 반영하지 못하고 있다. 왜냐하면 현재의 구속조건부 거래의 라목과 마목은 프랜차이즈 사업거래에 있어 온라인 상거래와 배달사업을 전혀 고려치 않고 있고, 가맹점의 사업활동에 대한 가맹본부의 부당성이 지나치게 포괄적으로 해석될 수 있기 때문이다.

가맹본부는 가맹점 간의 사업활동에 대한 첨예한 갈등을 줄이는 것은 물론, 자신의 업태와 업종의 특성에 부합하고 가맹사업의 목적성과 동일성을 좀 더 효율적으로 달성하기 위해 가맹점사업자의 판매 및 영업활동 형태와 방식에 대한 수직적 거래 제한을 할 필요성이 있다. 그러한 사업형태 또는 영업방식에 대해 미리 정보공개서와 가맹계약서에 이를 밝히고 가맹계약 체결과정에서 가맹희망자에게 충분히 설명하고 알린다면, 발생 가능한 가맹본부의 부당성은 상당히 희석시킬 수 있기 때문에 이러한 관점에서 현재의 가맹사업법의 구속조건부 거래의 라목과 마목은 재검토해야 할 필요가 있는 것이다.

다섯째, 이에 따른 제안으로 시행령 제 13 조 제(1)항의 '구속조건부거래'의 라목 '영업지역의 준수강제'의 제(1)의 제외요건의 수정을 제안한다. 그 방법으로 나목 '거래상대방의 구속' 제(3)의 예외요건과 다목 '가맹점사업자의 상품 또는 용역의 판매제한'의 제(2)의 예외요건의 주요한 내용인 '가맹본부가 미리 정보공개서를 통하여 
가맹점사업자에게 해당사실을 알리고 가맹점사업자와 계약을 체결할 것'을 활용하는 것을 고려해 볼 필요가 있다.

예를 들어, 라목 영업지역 준수 강제의 제(1)의 제외요건인 '가맹본부가 가맹점사업자의 영업거점지역을 정하는 행위'는 '가맹본부가 미리 정보공개서틀 통하여 가맹점사업자에게 해당 사실을 알리고 가맹점의 거래지역인 판매 및 영업활동 지역을 사전에 정하는 경우로 수정할 것을 제안한다. 이를 통해 가맹본부는 자신의 업태와 업종 그리고 사업의 목적성에 맞게 프랜차이즈 사업거래의 수직적 거래 제한의 긍정적 기능을 활용하여 가맹점 간의 사업활동에 대한 갈등과 충돌을 최소화할 수 있을 것이다.

여섯째, 동일한 방법으로 마목 '그밖에 가맹점사업자의 영업활동의 제한의 제(1)의 예외요건에 대해 나목 '거래상대방의 구속' 제(2)의 예외요건과 다목 '가맹점사업자의 상품 또는 용역의 판매제한'의 제(1)의 예외요건을 활용하여 수정할 것을 제안한다.

가맹점의 영업활동의 제한의 내용이 가맹본부의 상표권과 사업의 동일성을 유지할 수 있는 측면도 있지만, 최근에는 가맹점의 영업활동의 제한은 가맹점 간의 '경쟁'으로 인한 갈등과 충돌의 측면이 휠씬 더 강하다. 규모와 자본력이 큰 가맹점이 자유방임의 원리로 가맹본부가 시스템적으로 권장 또는 통제하는 판매가격과 영업방식의 근간을 훼손시키면서 배달 판매영업을 한다면, 인근 가맹점은 물론 가맹사업 자체까지 부정적인 영향을 미치는 것은 명백한 사실이 될 것이다.

따라서 현재 '가맹점사업자의 영업활동을 제한하지 아니하는 경우에는 가맹본부의 상표권을 보호하고 상품 또는 용역의 동일성을 유지하기 어렵다는 사실이 객관적으로 인정될 것'의 내용을 '가맹점사업자의 영업활동을 제한 또는 통제하지 아니하는 경우에는 가맹본부의 상표권을 보호하고 상품 또는 용역의 동일성을 유지하기 어렵거나 가맹점 간의 경쟁으로 인해 영업지역의 침해와 이로 인한 가맹점의 갈등이 심화될 우려가 객관적으로 인정될 것'으로 보완 또는 수정이 필요하다.

이와 같은 보완 또는 수정을 통해, 시행령 제 13 조 구속조건부 거래 마목이 가맹본부의 부당성을 지나치게 포괄적으로 해석할 수 있는 여지를 줄이고, 가맹본부가 자신의 업태와 업종의 특성을 기반으로 수직적 제한의 순기능을 활용을 통해 자신의 상표권과 사업의 목적성을 보호하고 가맹점 간의 지나친 경쟁으로 인한 갈등 유발의 요인을 자발적으로 줄일 수 있도록 도와야 할 것이다.

\section{2 정책기관의 대응 개선방향}

현재 공정거래위원회는 배달시장의 문제점의 해결을 위해 배달 앱 공급업자와 가맹본부에게 '상생의 경영'으로 이를 완화해 줄 것을
주문하고 있다. 그 정책적 슬로건은 옳다고 할 수 있겠으나, 현재에 직면한 문제점들을 실제적으로 해결해 주기에는 추상적인 면이 있다.

본 연구에서 공정거래위원회에게 제안하는 대응방안과 개선책은 아래와 같다. 먼저, 공정거래위원회는 '가맹사업 진흥에 관한 법률' 제 7 조 '실태조사' 제 1 항, 제 17 조 '자금의 지원'의 제 5 호, 동 법률 시행령 제 4 조 '실태조사의 범위 등' 제 1 호, 제 6 호, 제 7 호를 기초하여 현재 프랜차이즈 배달시장의 상황과 문제점에 대한 정확한 실태조사를 할 필요가 있다. 실태조사가 세밀하고 정확해야 실효성이 있는 정책적 과제를 도출할 수 있기 때문이다.

둘째, 해당 실태조사를 기초로 한 가맹사업법의 법 개정이 현실적으로 상당한 시간이 소요될 수 있기에, 공정거래위원회는 중단기적으로 무한경쟁의 배달 판매.영업으로 인한 가맹점 간의 충돌과 갈등을 완화시킬 수 있도록 관련 주체들의 의견을 수렴하여 '모범거래 기준안'을 마련하여 제시하거나 가맹본부와 가맹점 간의 '자율준수 프로그램(compliance program)'의 수립을 촉진할 수 있는 대책을 마련해야 한다.

배달 판매.영업의 '모범거래 기준안은 매장형 외식 프랜차이즈의 가맹본부가 가맹사업법을 위반하지 않고 현재의 무한경쟁의 배달상권으로 인해 발생하는 가맹점 간의 갈등을 완화 또는 최소화시키고자 하는 가맹본부의 자생적인 경영적 노력을 지지하고 지원해 줄 수 있다.

자율준수 프로그램은 기업들이 공정거래 관련 법규를 준수하기 위해서 자체적으로 제정, 운영하는 교육, 감독 등 내부 준법시스템으로, 가맹본부가 가맹점사업자와 상호협의하여 내부 준법시스템을 구축하여 스스로 자정적 차원에서 무한경쟁의 배달상권의 부작용을 완화시키는 할 수 있는 장치가 될 것이다. 그러나 자율준수 프로그램은 그 요건을 갖추는 것이 쉽지 않고, 이를 체계적으로 지속적으로 관리해야 하기에, 실무적으로 현재의 배달상권의 문제는 공정거래위원회가 '모범거래 기준안을 마련하여 가맹본부의 경영적 노력을 지지해 주는 방향으로 설정하는 것이 더 현실적이다.

예를 들어, '모범거래 기준안'을 통해 공정거래위원회는 매장형 외식 프랜차이즈가 가맹점의 배달의 민족의 울트라 콜의 이용갯수를 가맹점 주소를 기반으로 1 개로 제한하는 것을 장려할 수 있다. 음식 배달서비스의 배달범위를 현실적으로 $2-3 \mathrm{mk}$ 이상을 가진다는 것 자체가 문제이며, 이것은 과잉이라고 할 수 있다. 특정 가맹점이 다수의 울트라 콜의 설정하여 배달상권을 매우 넓게 설정하는 경우, 음식의 품질저하와 많은 배달비용의 발생을 유발하기에 오히려 소비자 후생의 감소가 발생할 수 있고 소비자의 불만족을 발생시켜 최종적으로 가맹본부의 브랜드 가치를 지속적으로 훼손시킬 수 있다. 또한 가맹점 간의 경쟁적인 울트라 콜의 설정은 배달 플랫폼의 매출증대와 소수의 자본력이 큰 가맹점의 이익에만 귀결되는 추세를 만들고 있기 때문이다. 
따라서 울트라 콜의 이용갯수의 제한은 자본력이 큰 가맹점의 배달사업의 독식을 막고 가맹점 간의 지나친 영업지역 침해와 첨예한 경쟁을 감소시킬 수 있기에 충분히 '모범거래 기준안'에 이를 권장할 필요가 있다.

제안할 수 있는 다른 예로, 특정 가맹점의 상당한 배달할인 쿠폰제공과 소비자의 배달음식의 도착가격을 상당히 차별적으로 낮추는 배달비용 무료의 판매정책에 대해서도 '모범거래 기준안'을 통해 가맹본부가 스스로 관리시키는 것도 고려해 볼 필요가 있다. 예를 들어, 신사역점이 단기매출과 시장확대를 목표로 상당한 할인쿠폰과 배달비용의 지원으로 공격적인 배달영업을 한다면, 좁게는 압구정역점의 매출은 감소할 것이고, 넓게는 가맹본부가 권장하는 메뉴별 판매가격 체계와 브랜드 영업방식의 시스템적 정체성을 약화시키고, 장기적으로 $\mathrm{A}$ 브랜드에 대한 소비자의 브랜드 신뢰성을 감소시켜 $A$ 브랜드의 사업 자체를 흔들 수 있다.

셋째, 가맹본부가 배달 판매.영업에 대해 합리적인 매뉴얼을 만들어서 이를 미리 정보공개서와 가맹계약서에 밝히고 가맹계약 체결과정에서 가맹희망자에게 충분히 설명하는 경우, 시행령 제 13 조에 기재된 '영업지역 준수 강제'와 '그밖에 가맹점사업자의 영업활동의 제한'의 불공정거래행위에 해당되지 않는다는 사실에 대해 공정거래위원회는 사전적 유권해석 또는 이에 준하는 가이드를 제시할 필요가 있다.

전술한 것과 같이, 현재의 대부분의 매장형 외식 프랜차이즈 가맹본부는 시행령 제 13 조 구속조건부 거래 금지의 법 규정으로 인해 현재의 무한경쟁의 배달시장에 대해 거의 아무런 조치도 취하지 못하고 있고, 발생하는 문제점들을 최소화하기 위한 선의의 전략을 수립하는 것에도 소극적일 수 밖에 없다.

넷째, 마찬가지로 시행령 제 13 조 불공정거래행위 유형 중 '거래지위상의 남용'의 다목 '부당한 계약조항의 설정 또는 변경'의 법 규정에 대해 공정거래위원회는 서론에서 질문한 Q5 와 Q6 의 어려운 상황에 가맹본부가 적절히 대응할 수 있도록 사전적 유권해석 또는 이에 준하는 가이드를 제시할 필요가 있다.

$\mathrm{Q} 5$ 와 Q6의 질문처럼 인근 가맹점에 의해 배달영업이 선점된 지역에 신규 가맹점이 출점 하는 경우, 가맹본부는 그 이전까지는 배달 판매.영업에 대해 제한 또는 통제를 하지 않았기 때문에, 현재로써는 가맹본부가 신사역점에게 그 지역의 배달 판매.영업의 철수를 강요하거나 가맹계약서 내용의 수정을 요구하기에는 법률적으로 쉽지 않기 때문이다.

마지막으로, 무엇보다도 공정거래위원회가 프랜차이즈 사업거래에 있어 수직적 거래 제한의 긍정적 기능과 역할을 전향적으로 이해하고 정책적 방향에 이를 활용할 필요가 있다.

최근 온라인 상거래가 프랜차이즈 사업의 유력한 사업형태로 떠 오른 것처럼, 앞으로 프랜차이즈 사업은 과학기술의 발전으로 인해 고도화될
것이다. 급속히 변화하는 사회에 적응하기 위해 그 만큼 법률과 제도도 포용적으로 또는 수용적으로 변화할 필요가 있다.

수직적 거래 제한은 프랜차이즈 사업에서 그 자체가 문제가 되지 않는다. 이를 가맹본부가 부당하게 활용하는 것이 문제인 것이다. 수직적 거래 제한이 경쟁의 감소를 유발하여 소비자 후생에 부정적 영향을 미칠 수 있지만, 많은 선행연구들은 프랜차이즈 사업거래에서 수직적 거래 제한의 순기능과 그 긍정적 역할에 대해 대부분 인정하거나 동의해 오고 있다(Affuso, 2002; Mathewson \& Winter, 1984; Rey \& Stiglit, 1988; Sass \& Sauman, 1996).

공정거래위원회가 수직적 거래 제한에 대해 전향적인 관점에서 긍정적 검토가 필요한 이유는 아래와 같이 국내 프랜차이즈 산업의 특성과 이에 따른 가맹본부의 출점전략의 특성에서 비롯된다.

첫째, 대부분의 가맹본부가 규모가 작거나 영세하다는 점, 둘째, 대부분의 가맹희망자의 창업자금의 규모가 작다는 점, 셋째, 이러한 영세성과 소자본 중심의 창업시장의 특징으로 가맹본부의 출점전략이 대부분 출점지역을 작게 분할하는 '소상권주의'라는 점, 넷째, 이러한 이유로 대부분의 매장형 외식 프랜차이즈의 영업지역(출점지역)이 반경 $500 \mathrm{~m}$ 정도 내외로 가맹점과 가맹점 간의 이격거리가 매우 짧다는 점에 있다.

이러한 사실은 현재의 울트라 콜로 대변되는 배달사업의 특성으로 인해 가맹본부가 자신의 업태와 업종에 맞게 가맹점의 배달사업을 제한 또는 통제하지 않고서는 현실적으로 가맹점 간의 영업지역 침해를 원천적으로 막을 수가 없다는 사실을 시사해 준다.

따라서 공정거래위원회는 가맹본부가 가맹점의 사업활동의 제한 또는 통제를 통해 가맹점의 권리와 이익을 침해하고 가맹점의 자율적인 경영활동을 방해할 수 있다는 과거경험적인 우려보다는 앞으로 가맹본부가 가맹점 간의 '경쟁'을 효율적으로 관리하여 가맹점 간의 갈등을 줄이고, 장기적으로 가맹본부가 자신의 업태와 업종의 특성에 맞게 가맹점의 운영비용을 감소와 브랜드의 운영의 효율성을 스스로 제고시킬 수 있도록 정책적으로 지원할 필요가 있다.

\section{3 가맹본부}

가맹점의 배달 사업활동을 제한 또는 통제하거나 반대로 자유방임으로 이를 통제하지 않는 것은 가맹본부가 스스로 판단할 문제이다. 그 사업전략에 대한 책임도 가맹본부에게 있다. 명확한 법 위반이 아니라면 어떠한 것이 옳고 잘못되었다라고 판단할 수는 없다. 그러나 분명한 문제는 광고를 기반하여 운영되고 있는 현재의 배달 앱 특성에 맞물려 가맹본부가 가맹점 간의 배달 판매.영업활동의 출혈경쟁을 지속적으로 방치하는 경우, 가맹본부의 브랜드 지속가능성을 위한 체력은 점차 고갈될 수밖에 없다는 사실에 있다. 
그렇다고 가맹본부가 법 해석의 명확성을 확인하기 위하여 가맹사업법의 보완이나 모범거래기준 또는 자율규제 시스템의 가이드를 막연히 기다리기에는 현실적 상황은 우호적이지 않다. 왜냐하면 서론에서 제기한 Q1 부터 Q6 의 사안들은 언제든지 가맹본부에게 언제든지 발생할 수 있기 때문이다.

따라서 현재의 배달시장에 대한 법률적, 제도적, 정책적 대안이 마련이 되기 전까지 매장형 외식 프랜차이즈 가맹본부는 아래와 같이 배달사업에 대한 운영전략을 마련하여 향후 발생할 문제와 갈등을 최소화시킬 수 있는 준비를 할 필요가 있다.

첫째, 시스템적으로 매장형 판매메뉴와 차이가 날 수 밖에 없는 배달 메뉴, 배달 음식의 양, 반찬의 양 등에 대해 배달 매뉴얼을 작성하고 이를 별도로 관리해야 한다. 즉, 배달사업의 특성을 반영하여 배달 판매영업방식에 대해 가맹점사업자에게 통일적으로 이행될 수 있는 배달 매뉴얼을 가맹본부는 별도로 마련하여 가맹점의 배달사업을 관리해야 할 필요가 있다.

둘째, 가맹점의 배달 판매영업의 방식, 예를 들어 표준 배달료 기준, 할인 쿠폰의 제공범위와 그 절차, 배달 판촉행사의 절차와 방법 등에 대해 매뉴얼을 수립해야 한다.

만약 이에 대한 가맹본부의 매뉴얼이 없다면 특정 가맹점이 상당한 할인쿠폰 제공, 배달비용 무료정책, 공격적인 소비자 유인의 판촉행사를 가맹본부의 통제없이 진행할 것이고 이로 인해 인근 가맹점의 피해와 가맹본부의 판매 및 영업방식의 시스템의 신뢰성이 훼손될 수 있기 때문이다.

셋째, 매장형 외식 프랜차이즈 사업에서 배달사업을 하는 목표는 가맹점의 전체적인 매출을 증가시키는 것인데, 배달사업으로 인해 실제적으로 가맹점의 전체 매출이 향상되고 있는지 아니면 매장의 매출이 줄면서 배달 매출만이 늘어나는 매출의 자기잠식(cannibalization) 현상이 일어나는지에 대해 최소한 분기별 또는 6 개월 단위로 이를 분석 및 평가할 필요가 있다.

넷째, 특정 가맹점의 배달 판매.영업 활동에 대한 소비자의 평가가 지속적으로 부정적으로 나오거나 배달서비스에 대한 가맹점의 운영수준이 표준 운영매뉴얼에 미치지 못하는 경우, 이에 대한 제제, 통제, 계약해지 여부 등에 대한 매뉴얼을 수립하고 이에 내용을 미리 정보공개서와 가맹계약서에 제시할 필요도 있다

다섯째, 배달사업의 매뉴얼과 가맹계약서 간의 관계성에 대해 명확한 설정도 필요하다. 가맹계약서가 배달사업의 매뉴얼을 통제하고 가맹계약서가 배달 매뉴얼보다 우선한다는 사실과 가맹점의 배달사업과 매장의 가맹사업이 서로 분리되지 않고 브랜드의 하나의 통합된 사업이라는 사실을 정확하게 밝히는 것이 배달사업의 과정에서 다양하게 발생하는 가맹점의 여러 문제들을 포괄적으로 관리하고 통제할 수 있는 기초가 되기 때문이다.
정리하자면, 이러한 가맹본부의 준비는 향후 지속적으로 성장할 가맹점의 배달 판매영업으로 인해 발생할 수 있는 문제들로부터 가맹본부가 가맹사업의 정체성과 사업목적성을 보호할 수 있고, 가맹점의 통일적이고 표준적인 운용이 훼손되지 않도록 최소한의 대비책을 마련하는 것으로 이해될 수 있다.

\section{0. 연구의 한계와 향후 연구방향}

본 연구의 한계와 향후 연구방향을 제시하면 아래와 같다.

첫째, 본 연구는 여러 보고서들, 선행연구의 고찰, 가맹사업법 검토를 통한 탐색적 연구방법에 의해 이루어졌다. 향후 연구에서는 무한경쟁의 배달상권에 대해 가맹점사업자와 가맹본부가 현실에서 어떠한 의견과 태도를 가지고 있는지 설문의 방법을 통한 실증적 연구를 진행할 필요가 있다. 다양한 차원의 실증연구는 정책기관의 효율적인 정책의 수립과 현실에 맞는 가맹사업법의 보완에 많은 기여를 할 것이다.

둘째, 프랜차이즈 사업거래의 영역에서 본 연구는 온라인 상거래, 온라인 상권, 배달상권을 이제는 가맹사업법에 포함시키는 것을 적극적으로 검토해야 할 시점이라고 주장하였다.

프랜차이즈 사업에서 온라인 상거래에 대한 논의와 가맹사업법의 적용여부는 상당히 많은 시간과 논의과정이 필요할 수 있다. 그러나 프랜차이즈 사업에서 온라인 상거래의 비중과 중요도는 지속적으로 증가될 것이고 이에 따른 많은 문제들이 가맹점 간에 첨예한 갈등으로 발생할 수 있기에, 이 진지한 논의의 촉진을 위해 앞으로 국내 프랜차이즈 산업의 특수성을 고려한 온라인 상거래에 대한 많은 사례연구들이 필요한 시점이 되었다.

셋째, 본 연구에서는 무한경쟁의 배달 판매.영업으로 인해 가맹점 간의 영업지역 침해, 가맹점의 운영비용 증가, 가맹점 운영의 피로도 증가, 자본력 있는 가맹점의 배달시장 독식 등의 문제로 인해 가맹점 간의 갈등과 대립이 발생한다고 지적하였다.

이에 대한 연구결과로써 본 연구에서는 가맹점의 판매활동, 영업활동, 마케팅 활동 등 사업활동이 인근 가맹점의 영업지역을 침해하여 해당 가맹점의 권리와 이익을 훼손시키거나 가맹본사의 브랜드의 사업목적성과 운영의 효율성을 저해시킨다면 이를 가맹사업법으로 이를 제한 또는 통제하는 것을 적극적으로 검토할 필요가 있다고 주장하였다.

가맹점사업자의 사업활동을 제한 또는 통제하는 것은 공정한 거래의 원칙에 비추어 볼 때 매우 민감한 주제이다. 이 주장에 대해 법률학자의 접근은 다를 수 있고, 정책기관의 해석과 입장 또한 다를 수 있다고 본다. 그러하기에 본 연구의 주장과 개선안에 대한 제안에 대해 앞으로 프랜차이즈 사업과 가맹사업법에 대한 전문적인 지식과 경험을 가진 
연구자 및 법률학자에 의해 다양한 관점의 또는 다른 차원의 접근에 의한 연구들이 많이 수행되어 합리적 방법으로 본 사안이 개선되고 보완되기를 기대한다.

마지막으로, 앞으로 경쟁과 관련된 수직적 거래 제한에 대한 다양한 이론 및 사례 연구들이 필요하다는 사실을 지적하고자 한다. 2020 년 공정거래위원회가 발표한 '2019 년 말 기준 가맹산업 현황'에 따르면 프랜차이즈 브랜드 수는 6353 개, 가맹본부는 5175 개, 가맹점 수는 25 만 4040 개로 모두 전년 대비 증가된 것으로 파악되었다. 브랜드 수와 가맹점 수를 고려해 볼 때, 앞으로 국내 프랜차이즈 사업거래에서 브랜드 간 또는 가맹점 간의 경쟁요인이 매우 중요한 논의대상이 될 것이다.

국내 프랜차이즈 산업에서 많은 브랜드의 난립과 창업시장에서 브랜드의 포화상태의 상황은 가맹사업법과 정책에서 앞으로 이들의 경쟁적 요인을 매우 중요하게 고려해야 한다는 사실을 말해 주고 있다. 그러한 이유로 앞으로 프랜차이즈 사업거래에 있어 경쟁과 관련된 수직적 거래 제한에 대한 많은 이론적 연구와 사례연구는 적합하고 효율적인 정책의 수립과 가맹사업법의 보완에 많은 기여를 할 것이다.

\section{1. 맺는 말}

매장형 외식 프랜차이즈에 있어 무한경쟁의 배달상권으로 인해 발생한 문제들은 현재 사회적으로 큰 이슈가 되고 있는 모빌리티사업자 '타다'의 사업과 '여객자동차운송사업법'과의 사회적 갈등의 사안과 본질적으로 유사하다.

폭발적인 온라인 플랫폼 사업거래의 발전은 기존 '여객자동차운송사업법'과의 충돌과 대립을 발생시키고, 이러한 변화는 현실적으로 손해를 보는 개인과 조직, 그리고 파생되는 소비자 후생의 문제를 어떻게 처리해야 옳은가에 대하여 우리 사회에 그 질문을 던지고 있는 것이다.

본 연구에서 제기한 제안과 시사점은 프랜차이즈 사업에 있어 폭발적으로 성장하고 있는 온라인 상거래, 온라인 상권, 배달상권에 대한 문제를 가맹사업법과 정책이 현재 적절하고 충분히 반영하고 이를 관리하고 있지 못하다는 문제의식에서 출발된 것이다.

본 연구는 현재의 상황이 명백한 누구의 잘못으로 기인한 것이 아니라, 사회가 변화하고 발전함에 따라 앞으로 지속적으로 발생할 수 있는 사회적, 경제적 문제 중의 하나이기에 관련 주체들이 좀 더 적극적으로 이 사안에 대해 논의를 할 필요가 있다는 관점에서 기반한다.

무한경쟁의 배달상권의 문제는 브랜드의 생존, 프랜차이즈 산업에 미치는 영향력, 증가하는 사회적 비용, 현실적인 가맹점 간의 갈등과
관련되어 있기에 현재의 '타다'와 '여객자동차운송사업법'의 충돌과 갈등보다 사회적으로 더 심각하다고 할 수 있다.

최근 시장점유율 1 위와 2 위 업체인 배달의 민족과 요기요의 기업합병이 성사된다면 독일 $\mathrm{DH}$ 사가 배달 앱 시장을 독점하게 가능성이 커지므로 앞으로 가맹점의 외부 시장환경이 한층 악화될 수 있다는 우려의 목소리는 본 사안의 심각성의 더욱 부각시키고 있다.

프랜차이즈 사업은 가맹본부와 가맹점이 신의성실의 원리에 입각하여 상호 동반성장을 하는 것을 철학적 기초로 하고 있다. 국내 프랜차이즈 사업은 국가 경제적으로 상당한 기여하고 있을 뿐만 아니라, 창업시장의 활성화, 고용창출, 실업률 감소 등 창업시장의 안전판으로써 사회적으로 많은 긍정적인 역할을 하고 있다. 그러하기에 프랜차이즈 사업의 건전한 발전을 위해 정책기관과 가맹본부가 현재의 배달시장의 문제를 해결하기 위해 좀 더 적극적인 노력이 필요한 것은 당연한 요구이다.

추상적인 상생협력의 구호가 아니라, 각 관련 주체들이 자신이 해야 하는 일을 충실히 하고, 상호 입장의 이해를 바탕으로 한걸음씩 먼저 다가서서 현재의 문제해결을 위해 적극적이고 구체적인 노력을 할 필요가 있는 것이다. 그러한 노력을 기초로 현재 무한경쟁의 가맹점의 배달 판매.영업이 인근 가맹점의 영업지역과 권리를 침해하고 가맹점 간의 갈등과 분쟁을 발생시킴으로써 프랜차이즈 산업의 정체성을 훼손하고 프랜차이즈 사업의 건전한 발전을 저해하지 않도록 앞으로 법률적 보완, 제도적 보완, 정책적 지원, 가맹본부의 스스로의 경영적 노력이 매우 필요한 시점이다.

\section{References}

Affuso, L. (2002). An empirical study on contractual heterogeneity within the firm: The 'vertical integrationfranchise contracts' mix. Applied Economics, 34(8), 931-944.

Benoliel, U. (2011). Criticizing the economic analysis of franchise encroachment law. Albany Law Review, 75(1), 205-225.

Carney, M., \& Gedajlovic, E. (1991). Vertical integration in franchise systems: Agency theory and resource explanations. Strategic Management Journal, 12(8), 607-629.

Chung, H. S., Choi, S. E., \& Choi, D. K. (2017). The effect of perceived risk, perceived benefits on purchase intention for delivery food. Korean Journal of Hotel Administration, 26(8), 71-86.

Cliquet, G., \& Voropanova, E. (2016). E-commerce and encroachment: Evidence from French franchise networks. Journal of Marketing Channels, 23(3), 114-128.

Dicke, T. S. (1992). Franchising in America: The development of a business method, UNC Press Books.

Du, Y., \& Tang, Y. (2014). Study on the development of O2O ecommerce platform of China from the perspective of offline service quality. International Journal of Business and Social Science, 5(4), 308-312. 
Gal-Or, E. (1991). Duopolistic vertical restraints. European Economic Review, 35(6), 1237-1253.

Jeong, H. D., \& Yoo, T. S. (2000). A study on consumer buying behavior according to fashion trading area. Journal of the Korean Society of Costume, 50(8), 165-175.

Kalnins, A. (2004). An empirical analysis of territorial encroachment within franchised and company-owned branded chains. Marketing Science, 23(4), 476-489.

Kang, J. W., \& Namkung, Y. (2019). The information quality and source credibility matter in customers' evaluation toward food $\mathrm{O} 2 \mathrm{O}$ commerce. International Journal of Hospitality Management, 78, 189-198.

Kaufmann, P. J., \& Dant, R. P. (2001). The pricing of franchise rights. Journal of Retailing, 77(4), 537-545.

Kim, T. H., \& Kim, H. S. (2016). Delivery app understanding and acceptance among food tech customers using the modified technology acceptance model, Journal of Tourism Sciences. 40(5), 127-144.

Kim, Y. J., Lee, J. U., \& Lee, Y. R. (2016). Analysis of properties of fashion trading areas using network analysis technique. Journal of the Korean Society of Clothing and Textiles, 40(2), 203-220.

Lafontaine, F., \& Shaw, K. L. (1999). The dynamics of franchise contracting: Evidence from panel data. Journal of Political Economy, 107(5), 1041-1080.

Lafontaine, F., \& Slade, M. (2014). Franchising and exclusive distribution. The Oxford Handbook of International Antitrust Economics, 2, 387.

Lee, H. (2014). Regulation on franchise encroachment under the Korea fair franchising act. Business Law Review, 28(4), 163200.

Lee, J. H. (2019). A study on the effect of the customer satisfaction and reuse intention of $\mathrm{O} 2 \mathrm{O}$ delivery service quality. The E-Business Studies, 20(5), 125-139.

Lee, S. D., \& Lee, Y. K. (2018). Visit push motivation for a trading area and flow, satisfaction, and revisit intention. Journal of Distribution Science, 16(9), 65-77.

Lee, S. D., \& Lee, Y. K. (2019). The empirical study on pull motivation for visiting a trading area and flow, attitude, and recommendation Intention. Journal of Product Research, $37(2), 179-195$.

Lim, Y. K. (2014). Regulations on territorial encroachment in franchising: Problems and future directions. Journal of Channel and Retailing, 19(2), 113-140.

Lim, Y. K., Lee, S. D., \& Kim, J. Y. (2012). A new exploratory research on franchisor's provision of exclusive territories. Journal of Channel and Retailing, 17(1), 37-63.

Mathewson, G. F., \& Winter, R. A. (1984). An economic theory of vertical restraints. The RAND Journal of Economics, 15(1), 27-38.

Michael, S. C. (1996). To franchise or not to franchise: an analysis of decision rights and organizational form shares. Journal of Business Venturing, 11(1), 57-71.

Nair, S. K., Tikoo, S., \& Liu, S. (2009). Valuing exclusivity from encroachment in franchising. Journal of Retailing, 85(2), 206-
210.

Norton, S. W. (2004). Towards a more general theory of franchise governance. In Economics and Management of Franchising Networks (pp. 17-37). Physica, Heidelberg.

Rey, P., \& Stiglitz, J. E. (1988). Vertical restraints and producers' competition. National Bureau of Economic Research, 32, 561568.

Rey, P., \& Stiglitz, J. (1995). The role of exclusive territories in producers' competition. National Bureau of Economic Research, 26(3), 431-451.

Roh, M., \& Park, K. (2019). Adoption of O2O food delivery services in South Korea: The moderating role of moral obligation in meal preparation. International Journal of Information Management, 47, 262-273.

Rubin, P. H. (1978). The theory of the firm and the structure of the franchise contract. Journal of Law and Economics, 21(1), 223 233.

Sass, T. R., \& Saurman, D. S. (1996). Efficiency effects of exclusive territories: evidence from the Indiana beer market. Economic Inquiry, 34(3), 597-615.

Shane, S. A. (1996). Why franchise companies expand overseas. Journal of Business Venturing, 11(2), 73-88.

Shen, C. W., Chen, M., \& Wang, C. C. (2019). Analyzing the trend of $\mathrm{O} 2 \mathrm{O}$ commerce by bilingual text mining on social media. Computers in Human Behavior, 101, 474-483.

Song, H. J., Youn, M. C., \& Chen, N. (2019). An integrated approach of decision making process for using delivery application: focused on AIDA model and MGB. Korean Journal of Hospitality \& Tourism, 28(4), 249-265.

Song, J. W., (2019). An effect of food delivery App service convenience of rising-generation single households on the continuous use intention: Focusing on moderating effect of willingness to pay delivery App service charge. FoodService Industry Journal, 15(3), 161-176.

Spinelli, S., \& Birley, S. (1996). Toward a theory of conflict in the franchise system. Journal of Business Venturing, 11(5), 329342.

Tae, K. S., \& Rhim, B. J. (2010). A study for locating of a new store considering competition for trading area: Focusing on the Case of Hypermarket in Seoul metropolitan area. Journal of the Korean Geographical Society, 45(5), 609-627.

Treece, J. M. (1967). Trademark licensing and vertical restraints in franchising arrangements. University of Pennsylvania Law Review, 116(3), 435-467.

Tsai, T. M., Wang, W. N., Lin, Y. T., \& Choub, S. C. (2015). An $\mathrm{O} 2 \mathrm{O}$ commerce service framework and its effectiveness analysis with application to proximity commerce. Procedia Manufacturing, 3, 3498-3505.

Vincent, W. S. (1998). Encroachment: Legal restrictions on retail franchise expansion. Journal of Business Venturing, 13, 29-41.

Yeo, V. C. S., Goh, S. K., \& Rezaei, S. (2017). Consumer experiences, attitude and behavioral intention toward online food delivery (OFD) services. Journal of Retailing and Consumer Services, 35, 150-162. 